\title{
Natural Resource Inventory and Monitoring for Ulaan Taiga Specially Protected Areas-An Assessment of Needs and Opportunities in Northern Mongolia
}

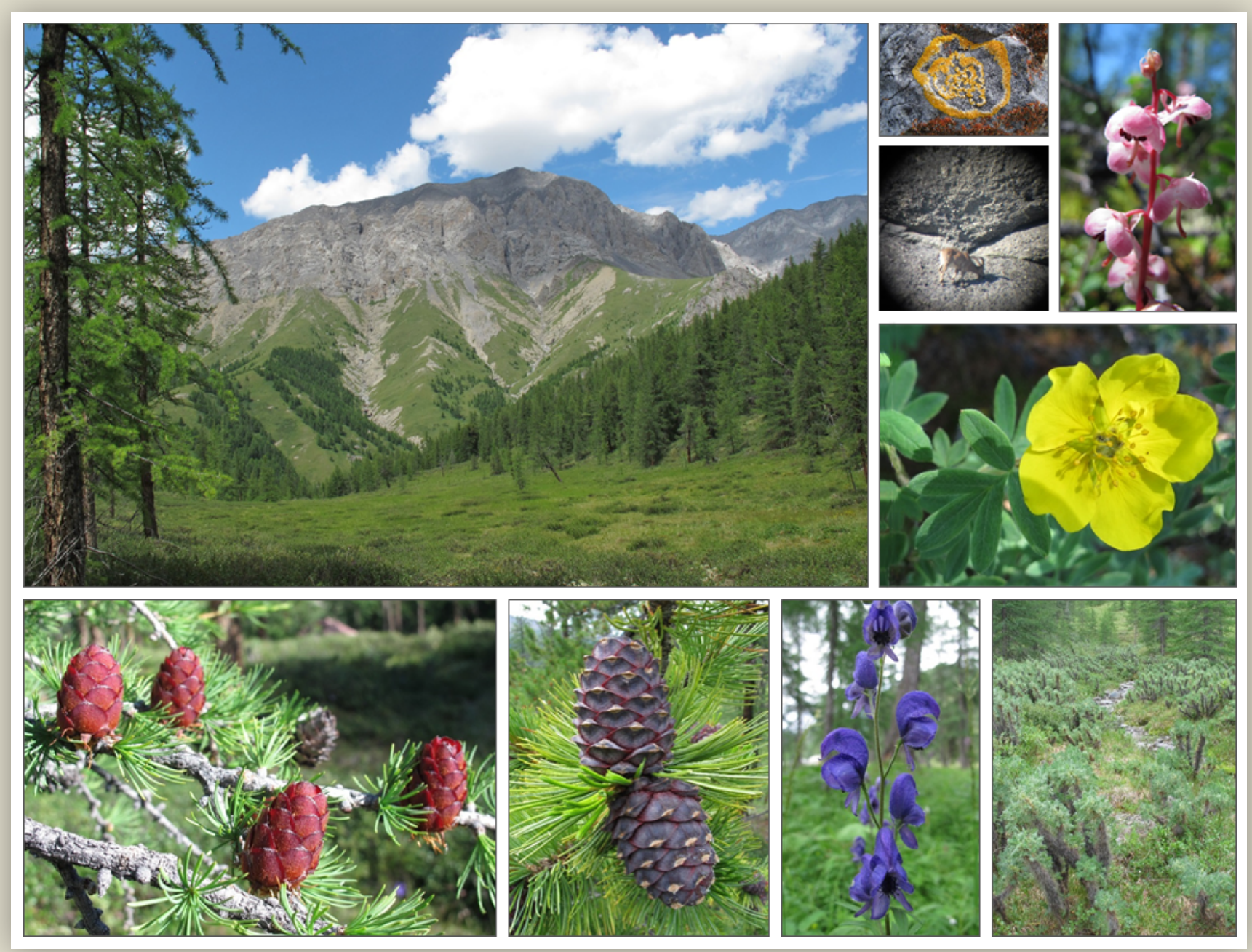

Open-File Report 2017-1025 
Cover: Native species of Horidol Saridag Strictly Protected Area, Hovsgol aimag, northern Mongolia.

Counter-clockwise from top left: Siberian larch (Larix sibirica) and Siberian ibex (Capra sibirica) habitat, Siberian larch branches and cones, Siberian pine (Pinus sibirica) cones and needles, monkshood (Aconitum cf. glandulosum), camel tail (Caragana jubata), shrubby cinquefoil (Dasiphora fruticosa), round-leaved wintergreen (Pyrola rotundifolia), crustose lichen, Siberian ibex. Photographs by Peggy E. Moore, U.S.

Geological Survey, July 2016. 


\section{Natural Resource Inventory and Monitoring for Ulaan Taiga Specially Protected Areas-An Assessment of Needs and Opportunities in Northern Mongolia}

By Peggy E. Moore, Joseph B. Meyer, and Leslie S. Chow

Open-File Report 2017-1025 


\section{U.S. Department of the Interior \\ RYAN K. ZINKE, Secretary}

\section{U.S. Geological Survey \\ William H. Werkheiser, Acting Director}

U.S. Geological Survey, Reston, Virginia: 2017

For more information on the USGS-the Federal source for science about the Earth, its natural and living resources, natural hazards, and the environment-visit http://www.usgs.gov/ or call 1-888-ASK-USGS (1-888-275-8747).

For an overview of USGS information products, including maps, imagery, and publications, visit http://www.usgs.gov/pubprod/.

Any use of trade, firm, or product names is for descriptive purposes only and does not imply endorsement by the U.S. Government.

Although this information product, for the most part, is in the public domain, it also may contain copyrighted materials as noted in the text. Permission to reproduce copyrighted items must be secured from the copyright owner.

Suggested citation:

Moore, P.E., Meyer, J.B., and Chow, L.S., 2017, Natural resource inventory and monitoring for Ulaan Taiga Specially Protected Areas-An assessment of needs and opportunities in northern Mongolia: U.S. Geological Survey Open-File Report 2017-1025, 35 p., https://doi.org/10.3133/ofr20171025.

ISSN 2331-1258 (online) 


\section{Acknowledgments}

Trust for Mutual Understanding (www.tmuny.org) provided support for the field review of natural resources and the associated effort to plan an inventory and monitoring program for the Ulaan Taiga Specially Protected Areas in Hovsgol aimag, northern Mongolia. Ono Batkhuu, Director; Robert McIntosh, board member; and the staff of the Mongol Ecology Center, including Tsenguun Tumurkhuyag and Chimgee Ganbold, provided exemplary coordination and assistance for all field and travel logistics and introduction to natural resources of the protected areas. Tumursukh Jal, Director of Ulaan Taiga Specially Protected Areas Administration, and the rangers and natural resources staff of the Ulaan Taiga Specially Protected Areas were instrumental in introducing us to the natural resources of the area and making the field visits possible. 
This page left intentionally blank 


\section{Contents}

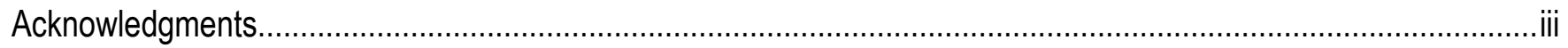

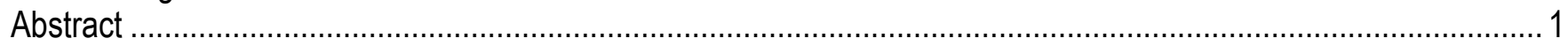

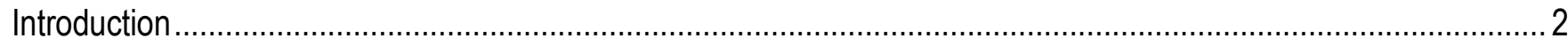

Goals

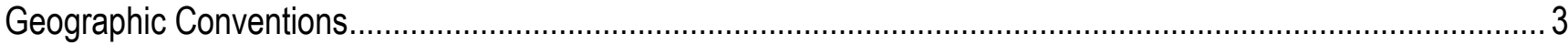

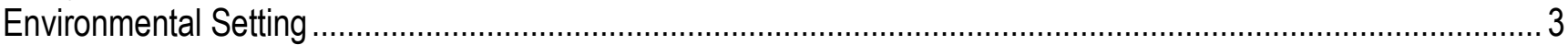

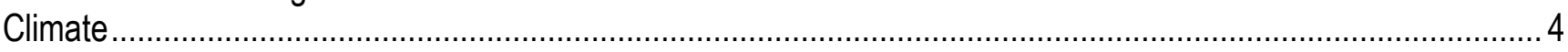

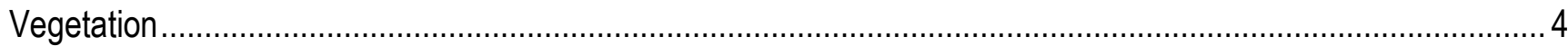

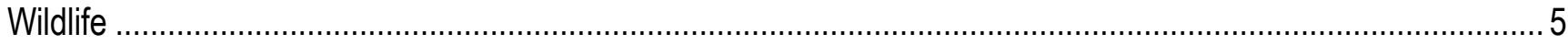

Fire

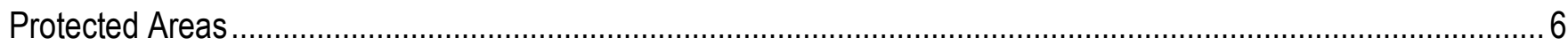

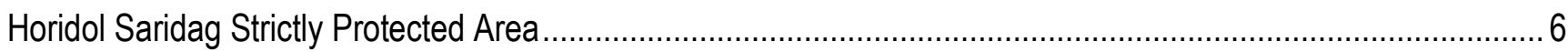

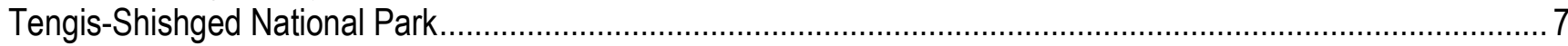

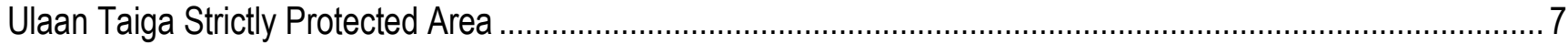

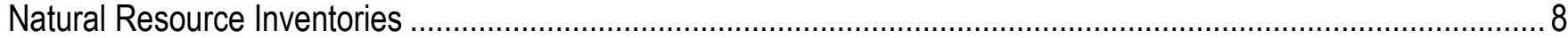

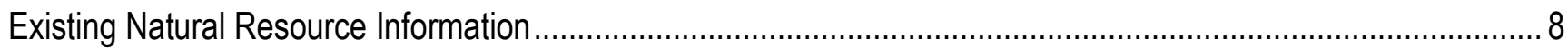

Vegetation and Land-Cover Classification and Mapping..............................................................................

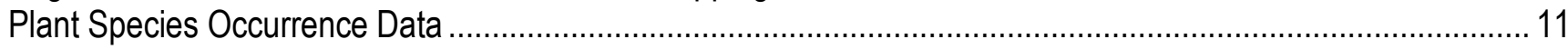

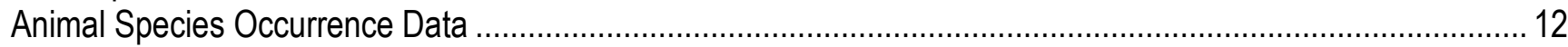

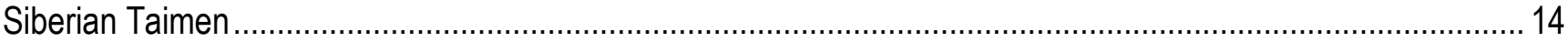

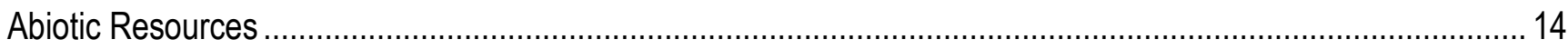

Spatial Data-Geographic Information System...................................................................................... 15

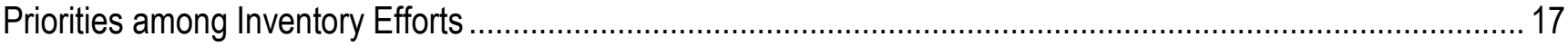

Monitoring

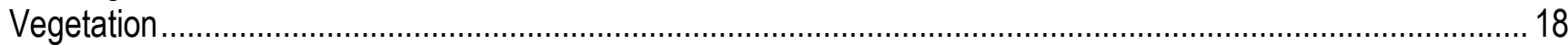

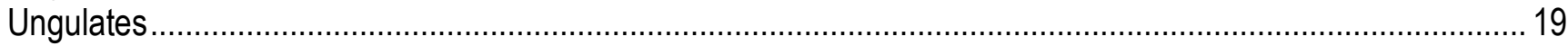

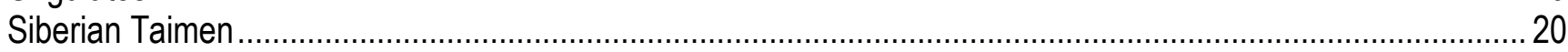

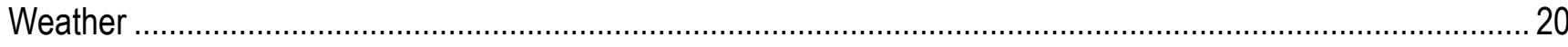

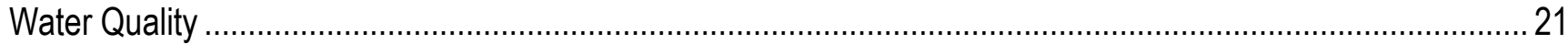

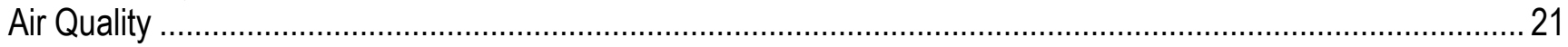

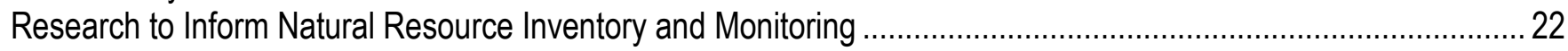

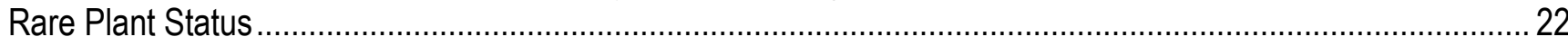

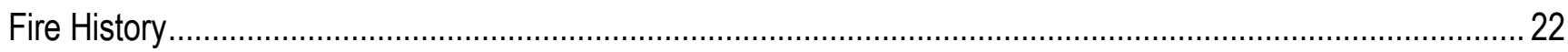

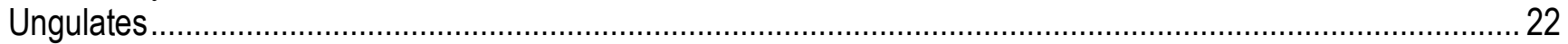

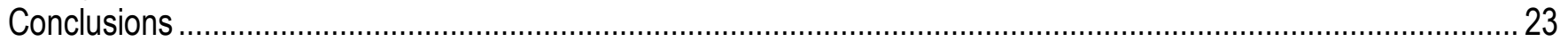

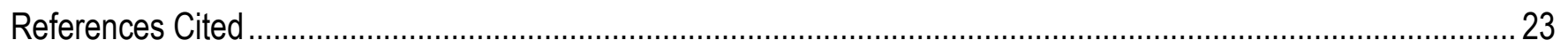

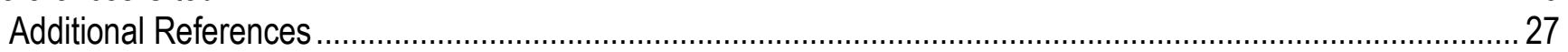

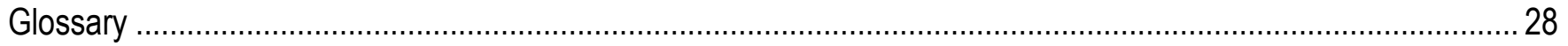

Appendix 1. Considerations Regarding Land-Cover Type Classification and Mapping for the Ulaan Taiga

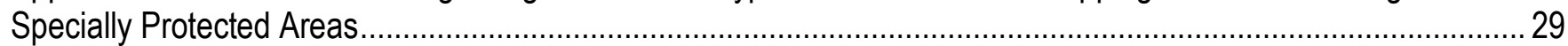

Appendix 2. Considerations for Documenting Plant Species Occurrence............................................................. 31

Appendix 3. Considerations for Documenting Faunal Species Occurrence......................................................... 33

Appendix 4. Using the International Union for the Conservation of Nature Species Mapping Tool to Generate a

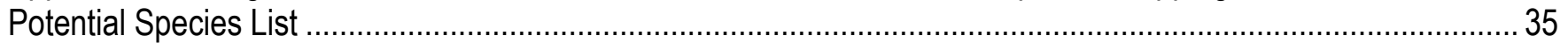




\section{Figures}

Figure 1. Map showing Ulaan Taiga Specially Protected Areas in the Hovsgol mountain region, Hovsgol aimag, northern Mongolia.

Figure 2. Photographs showing four altitudinal plant zones of the Hovsgol mountain region, Hovsgol aimag, northern Mongolia, July 2016

Figure 3. Photograph showing argali habitat within Horidol Saridag Strictly Protected Area, Hovsgol aimag, northern Mongolia, July 2016.

Figure 4. Photograph showing high-severity burn and recovery of shrub and herbaceous species after 7 years, Tengis-Shishged National Park, Hovsgol aimag, northern Mongolia, July 2016

\section{Table}

Table 1. Potential priorities among inventory efforts for the Ulaan Taiga Specially Protected Areas, Hovsgol aimag, northern Mongolia 


\section{Conversion Factors}

U.S. customary units to International System of Units

\begin{tabular}{lccc}
\hline & Multiply & By & To obtain \\
\hline & & Volume & \\
\hline gallon (gal) & 3.785 & liter (L) \\
\hline
\end{tabular}

International System of Units to U.S. customary units

\begin{tabular}{|c|c|c|}
\hline Multiply & By & To obtain \\
\hline \multicolumn{3}{|c|}{ Length } \\
\hline centimeter $(\mathrm{cm})$ & 0.3937 & inch (in.) \\
\hline millimeter (mm) & 0.03937 & inch (in.) \\
\hline meter $(\mathrm{m})$ & 3.281 & foot $(\mathrm{ft})$ \\
\hline kilometer (km) & 0.6214 & mile (mi) \\
\hline $\operatorname{meter}(\mathrm{m})$ & 1.094 & yard (yd) \\
\hline \multicolumn{3}{|c|}{ Area } \\
\hline hectare (ha) & 2.471 & acre \\
\hline square hectometer $\left(\mathrm{hm}^{2}\right)$ & 2.471 & acre \\
\hline hectare (ha) & 0.003861 & square mile $\left(\mathrm{mi}^{2}\right)$ \\
\hline \multicolumn{3}{|c|}{ Mass } \\
\hline kilogram (kg) & 2.205 & pound avoirdupois (lb) \\
\hline
\end{tabular}

Temperature in degrees Celsius $\left({ }^{\circ} \mathrm{C}\right)$ may be converted to degrees Fahrenheit $\left({ }^{\circ} \mathrm{F}\right)$ as ${ }^{\circ} \mathrm{F}=\left(1.8 \times{ }^{\circ} \mathrm{C}\right)+32$.

\section{Datums}

Vertical coordinate information is referenced to the North American Vertical Datum of 1988 (NAVD 88).

Horizontal coordinate information is referenced to the World Geodetic System of 1984 (WGS 84).

Elevation, as used in this report, refers to distance above the vertical datum.

\section{Supplemental Information}

Note to USGS users: Use of hectare (ha) as an alternative name for square hectometer ( $\left(\mathrm{hm}^{2}\right)$ is restricted to the measurement of small land or water areas. 


\section{Abbreviations}

$\begin{array}{ll}\text { GIS } & \text { geographic information system } \\ \text { IVC } & \text { International Vegetation Classification } \\ \text { NP } & \text { national park } \\ \text { NPS } & \text { National Park Service (United States) } \\ \text { SE } & \text { standard error } \\ \text { SPA } & \text { strictly protected area } \\ \text { spp. } & \text { species (plural) } \\ \text { USGS } & \text { U.S. Geological Survey } \\ \text { UTSPA } & \text { Ulaan Taiga Specially Protected Areas } \\ \text { UTSPAA } & \text { Ulaan Taiga Specially Protected Areas Administration }\end{array}$




\title{
Natural Resource Inventory and Monitoring for Ulaan Taiga Specially Protected Areas-An Assessment of Needs and Opportunities in Northern Mongolia
}

\author{
By Peggy E. Moore ${ }^{1}$, Joseph B. Meyer ${ }^{2}$, and Leslie S. Chow ${ }^{3}$
}

\begin{abstract}
Between 1997 and 2011, Mongolia established three specially protected areas in the northcentral part of the country to protect various high-value resources. These areas are jointly referred to as the Ulaan Taiga Specially Protected Areas. In accordance with the goals of the draft general management plan, this report identifies options for initiating an inventory and monitoring program for the three protected areas. Together, the three areas comprise over 1.5 million hectares of mountainous terrain west of Lake Hovsgol and bordering the Darkhad Valley. The area supports numerous rare ungulates, endangered fish, and over 40 species of threatened plants. Illegal mining, illegal logging, and poaching pose the most immediate threats to resources. As a first step, a review of published literature would inform natural resource management at the Ulaan Taiga Specially Protected Areas because it would inform other inventories.

Vegetation classification and mapping also would inform other inventory efforts because the process incorporates geographic analysis to identify environmental gradients, fine-scale sampling that captures species composition and structure, and landscape-scale results that represent the variety and extent of habitats for various organisms. Mapping using satellite imagery reduces the cost per hectare.

Following a determination of existing knowledge, field surveys of vertebrates and vascular plants would serve to build species lists and fill in gaps in existing knowledge. For abiotic resources, a focus on monitoring air quality, evaluating and monitoring water quality, and assembling and storing weather data would provide information for correlating resource response status with changing environmental conditions.

Finally, we identify datasets that, if incorporated into a geographic information system, would inform resource management. They include political boundaries, infrastructure, topography, surficial geology, hydrology, fire history, and soils.

In terms of tracking high-value resources, vegetation monitoring at the plot scale would provide a basis for detecting change in such characteristics as plant species composition, vegetation structure, and productivity that are associated with landscape-scale factors such as climate change or biotic interactions. Continued population monitoring of rare ungulates, particularly argali or wild sheep (Ovis ammon), would provide information on how populations are responding to natural and anthropogenic stressors. Siberian taimen (Hucho taimen) also is an important monitoring target given ongoing threats of poaching and climate change.
\end{abstract}

\footnotetext{
${ }^{1}$ U.S. Geological Survey.

${ }^{2}$ National Park Service.

${ }^{3}$ National Park Service (retired).
} 


\section{Introduction}

Mongolia has established 99 parks and protected areas, covering about 18 percent of the country. The first national park (NP), Bodg Khan Mountain Strictly Protected Area (SPA), was originally established in Ulaanbaatar in 1778. After the complete independence of Mongolia in 1990, the Law on Special Protected Areas of 1994 became the legal authority for establishing and managing protected areas. It includes rules and penalties that apply nationwide. The law establishes four distinct types of protected areas and levels of protection: (1) strictly protected areas, (2) national parks, (3) national reserves, and (4) national (heritage and cultural) monuments.

In this report, we address the natural resources of three protected areas in northern Mongolia, jointly referred to as the Ulaan Taiga Specially Protected Areas (UTSPA). They include Horidol Saridag SPA, established in 1997; Ulaan Taiga SPA, established in 2011; and Tengis-Shishged NP, established in 2011 (fig. 1).

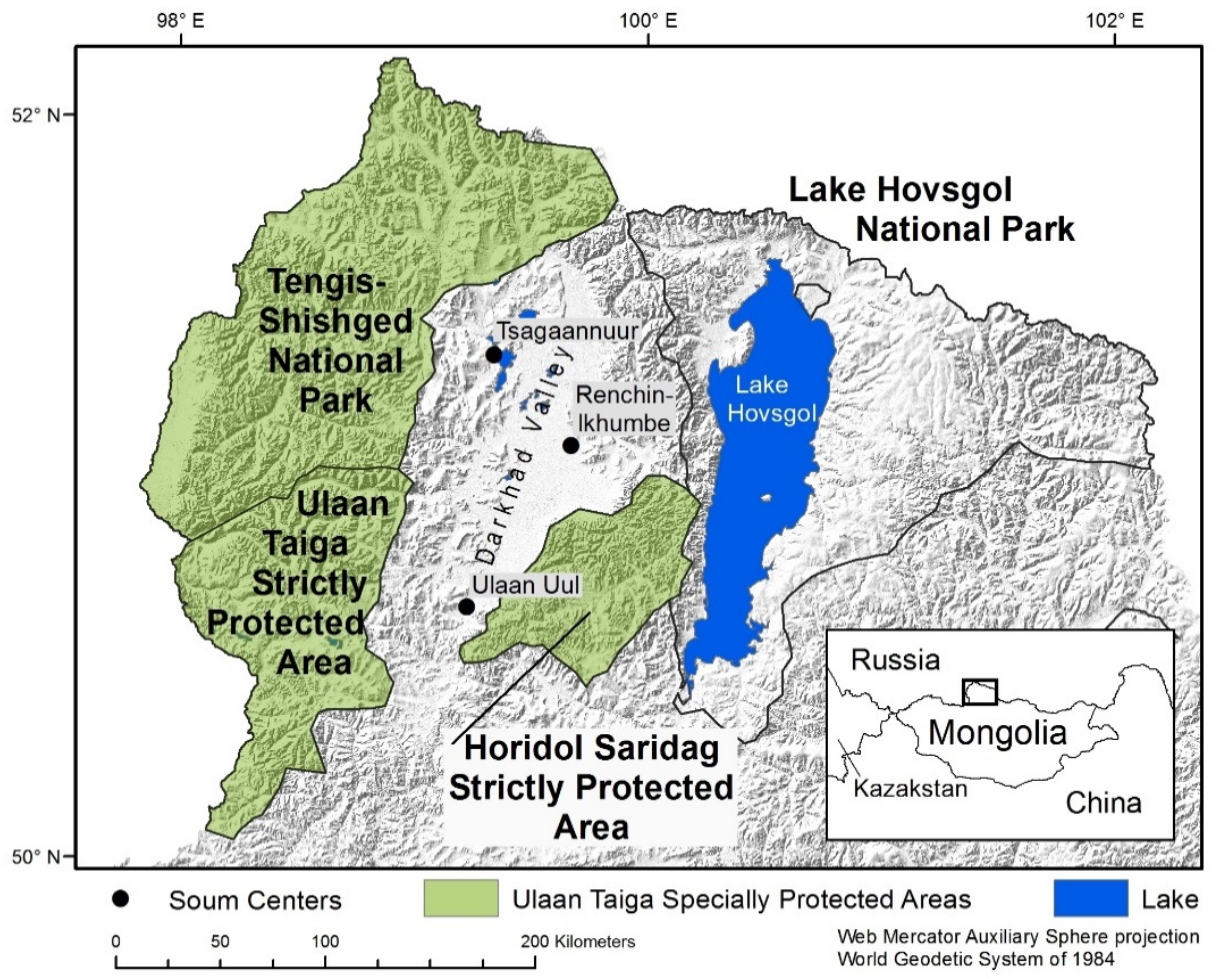

Figure 1. Map showing Ulaan Taiga Specially Protected Areas in the Hovsgol mountain region, Hovsgol aimag, northern Mongolia. Closed circles represent local administrative (soum) centers. 


\section{Goals}

The draft general management plan for the UTSPA identifies among its goals the collection of baseline information to populate a comprehensive resource database. Among the target resources in the plan are the appropriate inventories of water quality, water quantity, vegetation cover and distribution, and wildlife status to provide a scientific basis for protected area management decisions. Our primary goal is to identify the steps necessary for initiating an inventory and monitoring program for the three protected areas. In addition to resource status inventories, we identify spatial data on the distribution of landscape and resource features that, if acquired or created and assembled in a geographic information system (GIS), would be useful for management. Specifically our goals are to:

- Review natural resources and resource issues of Ulaan Taiga Specially Protected Areas,

- Identify and prioritize tasks to establish an inventory and monitoring program for the protected areas,

- Identify spatial datasets that would be useful information in a GIS, and

- Identify research efforts that would inform an inventory and monitoring program.

\section{Geographic Conventions}

This report uses the following conventions with regard to geography:

- Hovsgol aimag. Political "province" containing Lake Hovsgol NP, Ulaan Taiga SPA, TengisShishged NP, and Horidol Saridag SPA.

- Hovsgol mountain region. Northern part of Hovsgol aimag containing the three protected areas.

- Darkhad Basin. Watershed containing most of Ulaan Taiga SPA, Tengis-Shishged NP, and Horidol Saridag SPA.

- Darkhad Valley. The valley or generally low-gradient part of the Darkhad Basin. It is drained by Shishged Gol (river), which is part of the Yenisei River watershed

\section{Environmental Setting}

The Darkhad Valley is geographically central to the three protected areas. The valley is one of the three large basins in Mongolia and is located at the western end of the Baikal Rift (Logatchev and Florensov, 1978). Located in Hovsgol aimag of northern Mongolia, the Darkhad Valley is $100 \mathrm{~km}$ long from north to south and 20-40 km wide (Gillespie and others, 2008). The valley is drained through the west-flowing Shishged River, a major tributary of the Yenisei River, which drains to the Arctic Ocean. The Darkhad Basin is bounded on all sides by mountains, some reaching elevations of 3,300 $\mathrm{m}$. To the west is the Ulaan Taiga (red taiga), and to the east are the Horidol Saridag Mountains. Ulaan Taiga SPA and Tengis-Shishged NP lie within the Ulaan Taiga. The mountains around the Darkhad Basin were glaciated at least twice during the late Pleistocene (Batbaatar and Gillespie, 2016). The floor of the Darkhad Valley has shallow ground ice and other evidence of permafrost at varying depths that date from either the Holocene or, if ancient lakes were short-lived, from the Pleistocene (Batbaatar and Gillespie, 2015). Permafrost is otherwise widespread in the Hovsgol mountain region because of the severe continental climate (Sharkhuu and others, 2007) and local conditions (for example, lack of deep snow cover, vegetative cover; Heggem and others, 2006). 


\section{Climate}

The Hovsgol mountain region of northern Mongolia has an extreme continental climate with warm, wet summers and very cold, dry winters. The mean annual temperature at 1,573 m elevation at Renchinlkhumbe in the Darkhad Valley was $-6.9^{\circ} \mathrm{C}$ ( \pm 9.5 standard error [SE]) between 1975 and 2015 (National Agency for Meteorology, Hydrology, and Environmental Monitoring, 2016). Mean January temperature was $-32.3{ }^{\circ} \mathrm{C}$, and mean July temperature was $13.8^{\circ} \mathrm{C}$. Mean annual precipitation at Renchinlkhumbe was $263 \mathrm{~mm}( \pm 0.1 \mathrm{SE})$, with 71 percent of moisture received between June and August in the form of rain.

Mean annual temperature in the Hovsgol mountain region has increased by $1.68{ }^{\circ} \mathrm{C}$ over the last 40 years, an increase greater than the global average (Namkhaijantsan, 2006). Increases have been greater in winter than in summer (Batima and others, 2005).

\section{Vegetation}

Grubov (1982) described four major altitudinal vegetation zones that apply to the Hovsgol mountain region. Mountain forest steppe occurs between about 1,500 and 2,200 $\mathrm{m}$ in elevation, and forms a mosaic of mountain steppe on southern, eastern, and western exposures and Siberian larch (Larix sibirica) forest on cool, northern exposures (fig. 2A). Siberian larch is predominantly limited to permafrost soils. The herbaceous forest understory is a species-rich mix of forbs and grasses. There is evidence that the mountain forest steppe has lost a component of deciduous forest and seen the expansion of steppe and the retreat of needleleaved forest associated with wood extraction and grazing (Hilbig, 1995, p. 61).

The forest zone, between about 1,700 and 2,500 $\mathrm{m}$ in elevation, is dominated by Siberian larch (over 70 percent), with lesser components of Siberian pine (Pinus sibirica), Scots pine (Pinus sylvestris var. mongolica), and Siberian spruce (Picea obovata) (fig. 2B). Siberian fir (Abies sibirica) is on the national red list and is limited to small segments of the Hentii and Hovsgol mountain regions (University of Greifswald, 2010; Nyambayar and others, 2011). The herbaceous layer of the forest zone is rich in grasses and forbs, and shrub cover is common over a thick layer of lichens and mosses.

Upland forest is transitional between the forest and the alpine zones. Here, the Siberian larch and pines are shorter, shrub cover is abundant, and ground cover is dominated by mosses (fig. 2C). The alpine zone, above 2,000-2,200 $\mathrm{m}$ in elevation, is characterized by thin mineral soils and low-statured herbs (fig. 2D). Sedges (Carex spp., Kobresia spp.) are an important component, along with boreal herbaceous species and dwarf shrubs. 

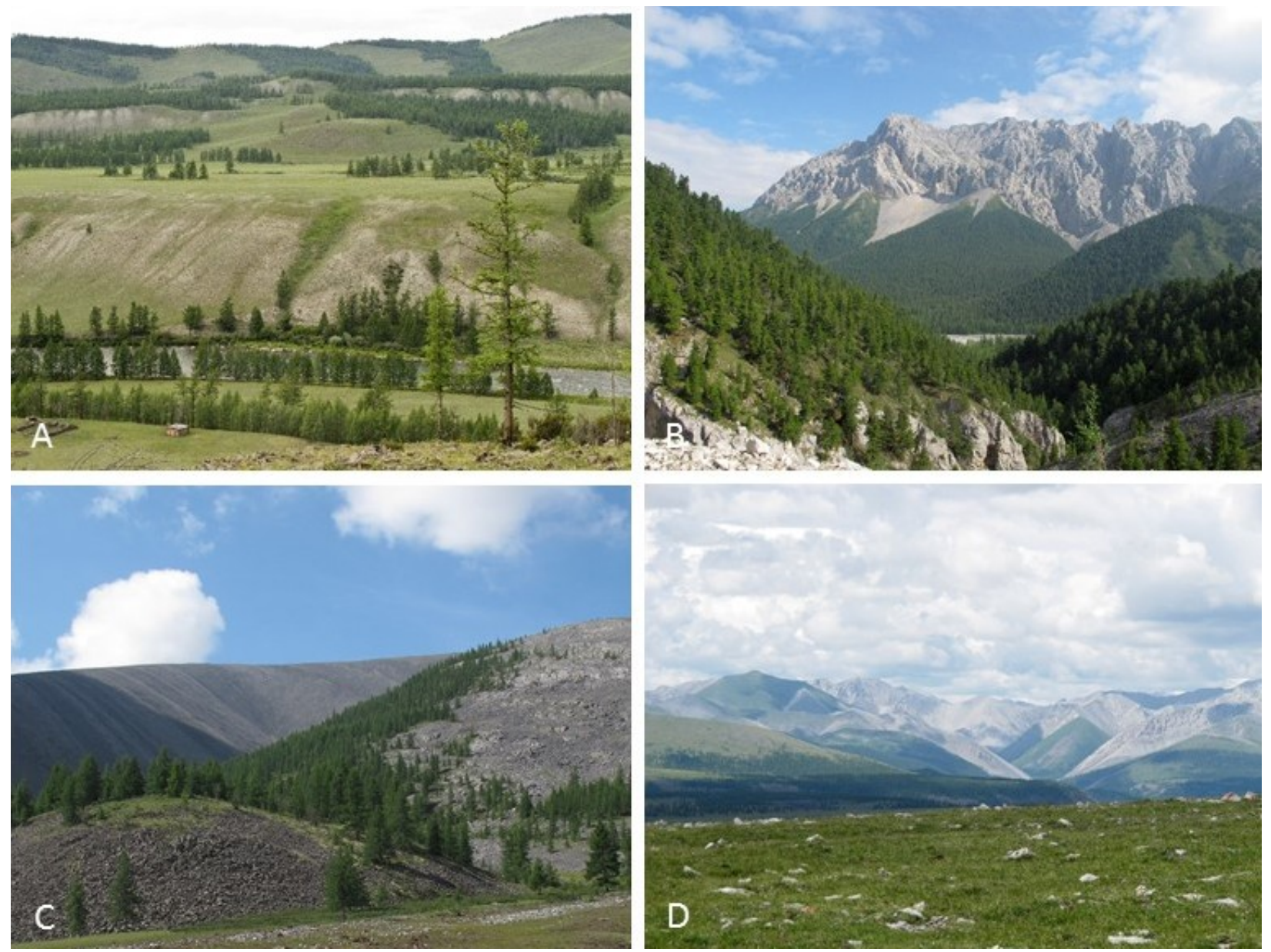

Figure 2. Photographs showing four altitudinal plant zones of the Hovsgol mountain region, Hovsgol aimag, northern Mongolia, July 2016. A, Mountain forest steppe zone (lower montane), B, Forest zone (upper montane), C, Upland forest zone (subalpine), and D, Alpine zone.

\section{Wildlife}

Based on species distribution models, there are 54-57 species of mammals, 8 species of fish, and 1 species of reptile predicted to occur within the UTSPA (International Union for the Conservation of Nature, 2016). There are approximately 202 species of birds reported for the Darkhad Valley (Nishida and Jamsran, 2009). The three protected areas are known for the variety of rare ungulates they support. These include red deer (Cervus elaphus), Eurasian elk (Alces alces), argali sheep (Ovis ammon), Siberian ibex (Capra sibirica), and Siberian musk deer (Moschus moschiferus). The Eurasian elk, argali, and Siberian musk deer are listed as endangered and the red deer is listed as critically endangered. The endangered Siberian taimen (Hucho taimen, family Salmonidae) occupies rivers in two of the protected areas. 


\section{Fire}

Forested lands comprise less than 12 percent (17.5 million ha) of Mongolia, occurring largely in the northern third of the country (Tsogtbaatar, 2004). Although logging and forest fires are commonly cited as the largest sources of forest degradation, logging activity more negatively affects vegetation composition and soil properties than fire (Park and others, 2010).

About 50-60 large forest fires occur annually in Mongolia, and measurable increases have occurred in the area burned since 1995 compared to the 15 years prior (Nyamjav and others, 2007). There is common consensus that 95 percent of forest fires are of anthropogenic origin (Nyamjav and others, 2007). Human sources of ignition are associated with non-timber resource extraction activities such as grazing and antler collection following moves toward a market economy in the early 1990s (for example, escaped camp fires, machinery sparks; Nyamjav and others, 2007).

The fire season is bi-modal, with 80 percent of fires occurring in the dry spring season (Aprilmid-June) and 5-8 percent occurring in the autumn (September-October; Valendik and others, 1998). Although natural sources of ignition are more present in the summer, summer fires are rare because of high fuel moistures associated with the season of greatest rainfall. Fire is common in the mountain forest-steppe zone, as well as in sub-taiga pine stands, with a mean fire return interval of 14-23 years (Valendik and others, 1998). Fire is less common in higher-elevation zones.

Reports differ on whether there have been increases in fire frequency compared with longer-term records. Scots pine and pine-larch stands in north-central Mongolia have had median fire return intervals of 12.6 and 9 years, respectively, over the last 175-215 years (Hessl and others, 2012). However, there is some evidence that the severity and extent of fires have increased (Ivanova and others, 2010; Hessl and others, 2012).

\section{Protected Areas}

\section{Horidol Saridag Strictly Protected Area}

Size: 227,413 ha Elevation range: $1,645-3,078 \mathrm{~m}$

The dramatic landforms within Horidol Saridag are the result of mountain-building processes and subsequent erosion. The dominant bedrock geology is limestone (Cambrian carbonates). Many caves occur within the protected area; however, only low-elevation caves have been studied. Horidol Saridag is drained largely to the north by the Arsai Gol (river), a tributary of the Shishged River.

Horidol Saridag SPA protects numerous rare ungulates, including Eurasian elk, red deer, musk deer, wild boar (Sus scrofa), and European badgers (Meles meles). The protected area may provide the highest quality habitat for wildlife among the three areas of the UTSPA (Tumursukh Jal, Director of Ulaan Taiga Specially Protected Areas Administration, oral commun., July 2016).

Family pastures and permanent human settlements are not present in Horidol Saridag SPA and habitat is still largely unmodified by human activities. Legal commercial timber cutting does not occur within the SPA because of protected status, nor within the buffer around the SPA because of poor access to commercial markets. Among the nearby local people, employment is low, and some use hunting as the main source of their livelihood. They also engage in renewable resource extraction (for example, antler gathering). Hunting is focused on red deer and musk deer. Employment opportunities for local people (throughout the Darkhad Valley) are largely in the areas of traditional livestock herding, tourism, a small service economy, and government positions, including rangers. 


\section{Logging and Poaching Threats}

Dead standing trees (for example, fire killed) and standing live trees are being unlawfully harvested. People use the harvested wood for fuel and building materials. Among the three protected areas, 13 cited violations occurred in 2013 (Nymgerel Ulzii, Ulaan Taiga Specially Protected Areas Administration, oral. commun., July 2016). Illegal logging occurs mostly in the Limited Use zone and in the development or buffer zone around the protected areas. Current solutions are law enforcement with associated fines and public education. In 2013, fines amounted to 87 million Tugriks (41,262 U.S. Dollars [USD]). Horidol Saridag supports populations of argali sheep and Siberian ibex. Both animals are poached for subsistence (meat) and for trafficking of horns and organs.

\section{Tengis-Shishged National Park}

Size: 869,070 ha Elevation range: $1,130-3,165 \mathrm{~m}$

The centerpiece of this vast area is the lower Shishged River that drains the Darkhad Valley as it flows west into Russia. The headwaters of the Tengis River drain the northernmost point of Mongolia. The park terrain predominantly is steep-sided, wide valleys carved by glaciers. Here and there, high peaks accentuate the horizon. The vegetation is Siberian larch forest on the slopes, shrubs on the flats, and wetlands on the valley floors. At the highest elevations, lichens dominate the ground cover.

Tengis-Shishged NP protects the traditional culture of the nomadic reindeer herders, the Dukha. In addition to Eurasian elk, red deer, musk deer, wild boar, and European badgers, wild reindeer (Rangifer tarandus) and Eurasian otters (Lutra lutra) inhabit Tengis-Shishged NP.

\section{Illegal Mining and Poaching Threats}

The area contains a known, commercially viable jade deposit.

Poachers include local people who live near the park and the in-park resident reindeer herders. Many poachers are well prepared with dogs to assist with locating game. Hunting originally was for subsistence, but the effect on wildlife has increased substantially because poachers now have access to commercial markets. Red deer have decreased from about 130,000 animals in 1986 to about 8,000 animals in 2016 because of exploitation and habitat loss. Poaching is kept in check through ranger patrols and monitoring of transportation routes. The taimen also are poached for commercial purposes.

\section{Ulaan Taiga Strictly Protected Area}

Size: 434,900 ha Elevation range: 2,655-3,351 $\mathrm{m}$ atop Mt. Belchir.

Ulaan Taiga SPA contains a landscape similar to that of Tengis-Shishged NP, but one distinguishing feature is a set of about 300 high-elevation lakes around Mt. Belchir. The area protects the headwaters for five large rivers in the upper Yenisei River Basin and supports abundant wildlife, including Siberian taimen, Eurasian elk, Siberian musk deer, and red deer.

\section{Illegal Mining and Poaching Threats}

Mining efforts, both historical and current local interest, focus on gold and jade. Following park staff discovery of 7,000 active miners, permanent settlements, and camps, UTSPAA staff removed the miners in 2012, burned camps, and cleaned up many tons of refuse. Cleanup, removal, and ongoing patrols are aimed at preventing the miners from returning.

Poaching targets the same species as in Tengis-Shishged NP. Since the eastern boundary of the SPA is a significant distance from people living in the Darkhad Valley, most poachers cross into the protected area via the western boundary over the national border with Russia. 


\section{Natural Resource Inventories}

Note regarding inventory suggestions or considerations and their implementation: When "UTSPAA" appears before a statement, we suggest that the UTSPAA continue to implement or implement the action. When "UTSPAA" does not appear, we assume that the UTSPAA will require outside technical and financial assistance to implement that management option.

\section{Existing Natural Resource Information}

In the 1990s, the National Park Service (United States; NPS) identified 12 basic natural resource inventories to be undertaken for all parks with significant natural resources (National Park Service, 2009). They were deemed necessary in order to adequately manage and protect resources in national parks. The 12 basic inventories were:

- Natural resource bibliography,

- Base cartography data,

- Air quality data,

- Air quality related values,

- Climate (precipitation, temperature),

- Geologic resources inventory,

- Soil resources inventory,

- Water body location and classification,

- Baseline water-quality data,

- Vegetation classification and mapping,

- Species lists (vertebrates and vascular plants), and

- Species occurrence and distribution.

These inventories were intended to be spatially extensive (that is, park-wide) but to indicate the status of the resource at a single point in time. They included the status of biological resources, such as plants and animals, and abiotic resources such as air, water, soils, landforms, and climate. They involved the compilation of existing information and the acquisition of new data.

The natural resource bibliography is at the top of the list because the process of compiling it informs many other efforts. Much research has been done in northern Mongolia, and the Hovsgol mountain region in particular, that can inform management at the UTSPA. This includes work on permafrost, species occurrence, fire history, plant communities, climate patterns, and geology. Much of the work is in Russian or German, but some is available in English, in English translation, or with English summaries.

\section{Bibliography Considerations}

- A thorough literature review and compilation of an associated bibliography and library (electronic) on natural resource topics where work was done in the Hovsgol mountain region would help inform management of UTSPA.

- An assessment of the degree to which publications from the joint Russian-Mongolian expeditions beginning in 1970 are available in translation to English or Mongolian would inform any bibliographic tasks. 


\section{Vegetation and Land-Cover Classification and Mapping}

Vegetation and land-cover maps represent the location and spatial extent of classes according to a prescribed classification of biotic and abiotic components on the landscape. Classes may include vegetation types, vegetative cover densities, and classes of rock (for example, bedrock), water, and ice cover. Vegetation and land-cover maps have broad utility in resource management applications. They can serve as a basis for habitat mapping or modeling, and be used to assess the abundance and structure of forest fuels and, therefore, potential fire behavior.

Vegetation classification and mapping typically involves:

- Image analysis (aerial photograph interpretation or satellite imagery analysis) to identify areas with homogeneous cover characteristics;

- Field sampling to collect detailed data on species composition, vegetation structure, and environmental factors;

- Data analysis to group samples into classes;

- Labeling imagery with classes from the classification; and

- Map accuracy assessment.

Hilbig (1995) summarized previous work by Russian and German ecologists to classify the vegetation of Mongolia. With published descriptions for many plant communities, sampling could be limited in some cases to verifying the location and composition of published vegetation types occurring within the UTSPA. For example, previous work has described Siberian larch forest, Siberian pine forest, round-leaved dwarf birch (Betula rotundifolia) and camel tail (Caragana jubata) plant communities, among others, for Hovsgol. Although six different associations have been described for Siberian larch forests, each differing in composition and environmental setting, the goal of mapping likely would involve one class for larch forest representing all the associations, one class for Siberian pine, and perhaps a subalpine and montane shrubland class to represent the dwarf birch and camel tail shrub types. Considerations of cost and management needs will inform decisions whether to map at the middle or lower levels of the International Vegetation Classification (IVC) hierarchy.

\section{Satellite Imagery}

Digital image processing of satellite imagery often is the first step in mapping vegetation and land cover. Vegetation and land-cover classes identified in a classification must produce distinct spectral signatures in the imagery in order to be distinguished by remote sensing.

Landsat Thematic Mapper imagery likely remains the most cost-effective method of obtaining vegetation and land-cover information for large areas. The resolution of Landsat imagery is $30 \times 30 \mathrm{~m}$. Imagery and ancillary data would be georeferenced to a single standard projection (for example, Geographic Coordinate System Monref 1997). The goal for registration accuracy often is set to \pm 1.0 pixel. If feasible, extending the mapping extent for the UTSPA beyond the specific protected area boundaries to include buffer zones around the protected areas and the entire Darkhad Valley would provide management with the most comprehensive information.

Following classification of the imagery, ancillary data such as elevation, aspect, illumination, soils, and surficial geology can be used to differentiate vegetation classes not well distinguished in the imagery (for example, shadow compared to water and lowland shrub types compared to upland shrub types; Markon and Wesser, 2000). 
The UTSPA comprise over 1.5 million ha. Other areas with comparably large landscapes and diversity of vegetation types provide examples of efficient and cost-effective mapping. One example that may provide useful methods is the approach of the Alaska Land Cover Inventory Program for classifying, describing, and mapping vegetation (http://science.nature.nps.gov/im/units/akro/inventory/ landcover.cfm). Another example of mapping large landscapes is that of von Wehrden and others (2006) for the Gobi Gurvan Sayhan NP. Such approaches can be refined for the UTSPA based on current, standard technologies and techniques.

More detailed information about considerations related to a vegetation and land-cover classification for the UTSPA is available in appendix 1.

\section{Map Accuracy}

An important component of vegetation or land-cover mapping is accuracy assessment. This can be done using a portion of the original field samples (plots) withheld and not used in the classification or new data collected for the estimating accuracy. Ideally accuracy estimates are made for all classes of the map. However, more samples can be allocated to types for which greater confidence in accuracy estimates is advantageous to management. With the size, remoteness, and cost of accessing parts of the UTSPA, there may be an advantage in implementing sampling for classification and accuracy assessment in a single effort.

\section{Vegetation Classification and Mapping Considerations}

- Expert assistance in the design and implementation of a vegetation sampling, classification, and mapping project would maximize efficiency.

- For the sizeable landscapes of the UTSPA, satellite imagery classification is the most efficient approach for vegetation mapping, perhaps further informed by ancillary data.

- Extending mapping areas to protected area boundaries and, if feasible, designated buffer zones and the entire Darkhad Valley would provide the maximum amount of information for management.

- Following a set of established standards for vegetation classification and description, such as those of the U.S. Federal Geographic Data Committee (Federal Geographic Data Committee, 2008; Faber-Langendoen and others, 2014), would produce the best-quality products.

- Project scoping is the appropriate time to determine mapping class resolution.

- Project deliverables ideally will include:

- Vegetation and land-cover mapping report (including detailed methodology on image analysis, ancillary data analysis, field methods, land-cover classification);

- Satellite imagery and associated products;

- Digital vegetation map;

- Vegetation plot data;

- Accuracy assessment plot data, analysis, and error matrix specifying accuracy by type;

- Dichotomous key to vegetation classes; and

- Vegetation and land-cover class descriptions. 


\section{Plant Species Occurrence Data}

Humans derive many benefits from natural systems and their biota in the form of ecological services. These include amelioration of climate effects, biogeochemical cycling, hydrological functions, soil health and retention, pollination, pest control, recreation and ecotourism (Myers, 1996). There is a close relationship between ecosystem functioning and biodiversity (Hooper and others, 2005). A fairly comprehensive understanding of species occurrence in protected areas is the first step in conserving the biodiversity that supports these functions. Assessing rarity or identifying species of limited distribution among those occurring in protected areas assists with identifying management priorities. Species inventories also provide a framework for understanding and exploring ecological relationships.

The known vascular flora of Mongolia consists of 3,127 species and subspecies in 112 families (Urgamal and others, 2014). Since the publication of Gubanov (1996), 412 taxa have been added (Urgamal and others, 2014). Additions were based on literature and careful review of specimens at the National University of Mongolia and the Institute of Botany at the Mongolian Academy of Sciences. Of the total, 153 species, 5 percent of the flora, are endemic. Hovsgol is among the top 5 most diverse of 16 phytogeographic regions in the country (Grubov, 1982), with 34 percent of the national flora or 1,078 species (Urgamal and others, 2014). The national red list has 110 species of plants (Nyambayar and others, 2011). Of these, approximately 41 species occur within the Hovsgol mountain region, 6 of them listed as critically endangered, 9 as endangered, and 18 as vulnerable (Nyambayar and others, 2011).

Locating existing documentation of species occurrence is the most cost-efficient approach to determining the current state of knowledge on species occurrence. As a result, building a species list by protected area could begin with locating specimens collected from within the areas and accessioned at various institutions (for example, museums, herbaria). For example, vascular plant records in FloraGREIF, a database being populated with Mongolian specimen data from German universities (http://greif.uni-greifswald.de/floragreif/), has thousands of collections from Mongolia. Additions to species lists can then be made as additional species are documented from within protected areas using, for example, NPS Inventory and Monitoring Program standards for acceptable documentation, including accessioned specimens, high-quality georeferenced photographs, or published accounts, as appropriate.

More detailed information on considerations related to documenting plant species occurrence is available in appendix 2 .

\section{Plant Species Occurrence Considerations}

- UTSPAA - Continuing the current program of rangers recording occurrence data on plant species will contribute observational data toward developing species lists by protected area.

- UTSPAA - Recording plant observation coordinates using GPS, once GPS training and equipment become available, would provide more precise locations for observational data.

- The NPS considers museum specimens and high-quality publications to form the most reliable evidence of species occurrence by protected area.

- Details from existing herbarium specimen labels can be stored as evidence of species occurrence by protected area, including species name, collector, collection number, date, and location.

- Well-designed field surveys provide opportunities to collect specimens for documenting additional taxa and adding to the information on species distributions.

- Documenting the presence of additional species also can be accomplished during opportunistic surveys of small-scale or more specialized habitats that might support rare species. 
- Depositing newly-collected specimens at a curated institution provides a long-term record of species occurrence and the ability to update identifications as taxonomic changes occur.

- A well-designed relational database for species occurrence data can be designed to store (1) detailed specimen data (for example, determination, size, flower color), (2) collection data (for example, collector, location name, location coordinates, environmental setting), and (3) full species list with attributes (for example, plant family and status as native or non-native for each species).

\section{Animal Species Occurrence Data}

Of the 141 mammalian species known from Mongolia, 60 occur in northern Hovsgol, making the area among the most species-rich areas in the country (Clark and others, 2006; Batsaikahn, 2014). This also is an area with some of the largest deficits in data, defined as where there is insufficient information to assess extinction risk with any confidence (Clark and others, 2006). Although large ungulates and carnivores have been well studied in Mongolia (Maroney, 2005), information on medium and small vertebrates seems to be lacking. Of the 476 bird species in Mongolia, 36 are listed as threatened (Gombotaatar and others, 2011). However, Mongolia has a lower proportion of species listed as threatened than the global average of 21 percent (Gombobaatar and others, 2011).

There are 24 species of reptiles and amphibians recorded for Mongolia, with higher species richness of reptiles in the south and higher richness of amphibians in the more forested and mountainous north (Terbish and others, 2006). Among the total, distribution maps indicate that one amphibian, the Siberian salamander (Salamandrella keyserlingii, listed as vulnerable), and two reptiles can be expected within the Hovsgol mountain region (Terbish and others, 2006).

Mongolia has 78 species of fish, 2 of which are introduced (Kottelat, 2006) and 13 of which are listed as endangered, vulnerable, or near threatened (Ocock and others, 2006). Eight fishes, four of them threatened, can be expected in the UTSPA ${ }^{4}$. We were unable to find published faunal surveys or specimen records for the UTSPA in English, German, or Mongolian, and the extensive literature in Russian has been unavailable to us.

Existing evidence of species occurrence or the collection of new evidence can form the basis for compiling species lists for the UTSPA. The objective of creating species lists is to document the faunal species present in each of the three protected areas to assist protected-area managers with conservation and management. Inclusion of a taxon on a species list is supported by evidence in the form of either a voucher specimen accessioned in an accredited institution, an observation confirmed by a supporting photographic image, or a published account specifying occurrence in the protected area. Voucher specimens are preferred because they are the most reliable form of evidence and can provide significantly more information than a photograph or published account. However, if collecting specimens is incompatible with cultural beliefs or practices, photographic images and published accounts are a significant contribution.

\footnotetext{
${ }^{4}$ The Mongolian national red list indicates the following fishes may occur within the UTSPA: Siberian stone loach (Barbatula toni; Least Concern), Siberian spiny loach (Cobitis melanoleuca; Least Concern), common minnow (Phoxinus phoxinus; Least Concern), Arctic whitefish (Coregonus pidschian; Endangered), Arctic grayling (Thymallus arcticus; Near Threatened), lenok (Brachymystax lenok; Vulnerable), taimen (Hucho taimen; Endangered), burbot (Lota lota; data deficit).
} 


\section{Specimen Records}

Locating existing, curated specimens from the protected areas is the most efficient and costeffective approach to compiling faunal species lists because it typically can be accomplished using internet searches. For example, VertNet (http://portal.vertnet.org/search), a consortium of research institutions and natural history museums, serves online specimen records from across the globe with details including collection locality, collector, date, and accession number. Specimen records also may be available through online databases hosted by individual museums and universities.

Another source of specimen records is a thorough literature review of all relevant publications on research studies done in the UTSPA. This method often will yield results for a single taxon or taxonomic group and, hopefully, will provide information about the location and disposition of any specimens collected during the course of the study. This approach has the added benefit of building a bibliography that can be used for other purposes.

Finally, species lists can be compiled using distribution maps depicting the known or predicted occurrence of a species based on habitat and life history requirements. However, this represents modeled, not empirical, data, and the best use of distributional information probably is the construction of potential species lists.

Species predicted to occur within the protected areas but unsubstantiated by existing specimens may require field surveys to confirm their presence. Surveys that generate new specimens provide physical evidence of species occurrence while populating the species list for each survey location. Although the implementation of a field survey is relatively straightforward, it also will require a statistically robust study design and logistical support.

More details regarding considerations for documenting animal species occurrence are available in appendix 3.

\section{Animal Species Occurrence Considerations}

- UTSPAA - Continuing the current program of rangers recording observations of carnivores, ungulates, and other animal species will contribute data for species lists by protected area.

- UTSPAA - Recording animal observation coordinates using GPS, once GPS training and equipment become available, will provide more precise occurrence data.

- UTSPAA - If rangers received training on collecting photographic evidence, they could add animal sign (such as, scat and tracks) to their reported observations along with GPS coordinates.

- Adding birds to incidental and opportunistic wildlife observation records to those collected by the UTSPAA rangers would serve to begin building bird species lists by protected area.

- A relational database is likely the most efficient place to store and manage observational data.

- A search of museums and universities in Mongolia as well as institutions in Europe and Russia might locate specimen records from the UTSPA.

- Publications produced by the joint Russian-Mongolian expeditions that began in 1970 might have information about specimens from UTSPA collected during the expeditions.

- Publications resulting from research studies conducted in the Darkhad Valley and the UTSPA offer another source of information on specimens or species occurrence.

- The International Union for the Conservation of Nature Species Mapping Tool (www.nationalredlist.org/support-information/tools-red-lists/tools/; appendix 4) offers the opportunity to develop lists of species predicted to occur in UTSPA.

- Identifying academic collaborators offers the best opportunity to implement Grinnell-style field surveys (Moritz and others, 2008, 2011) for vertebrate species in the UTSPA. 


\section{Siberian Taimen}

The taimen is distributed from western (Volga River) and northwestern (Pechora River) Russia east to eastern Siberia (Yana River) in the north and northeastern China (Amur River) in the south. In Mongolia, the taimen is in both the Arctic (Yenisei River) and Pacific (Amur River) drainages. The taimen is in Tengis-Shishged NP and the Ulaan Taiga SPA. One of the largest salmonids in the world, mature taimens can weigh $15-30 \mathrm{~kg}$. Average length is 70-120 cm, and they can live as long as $55 \mathrm{yr}$. The taimen is listed on the Mongolian national red list as endangered (Ocock and others, 2006).

In the Shishged River, the number of taimen in sein surveys declined between 1995 and 2009, and fish were reduced in size and weight. Spawning dates were a few days earlier in 2009 than in 1995, attributable to higher stream temperatures in response to a warming climate.

\section{Taimen Consideration}

Either recently published work or field surveys would be valid sources for determining the status of Siberian taimen populations and related water temperature and water quality conditions within Tengis-Shishged NP and Ulaan Taiga SPA.

\section{Abiotic Resources}

\section{Weather/Climate}

Reliable weather data over long durations provide critical information to managers and are essential to understanding how climate change may be affecting resources. They also are useful in drawing conclusions about ecological changes and changes in climate. Understanding weather and climate also is essential to managing resources as climate change occurs. Climate is one of six vital monitoring targets of the NPS Sierra Nevada Network Inventory and Monitoring Program.

There are two weather stations in the Darkhad Basin, both on the Darkhad Valley floor. They are in the soum (approximate equivalent to county level of government subdivision) centers of Ulaan Uul (elevation 1,698 m) and Renchinlkhumbe (elevation 1,573 m). We inspected the weather station at Ulaan Uul, and it appears to be a manual station that records daily minimum and maximum temperature as well as precipitation. There is a wind speed and direction indicator, but we did not discover how data are recorded. Reportedly, the station at Renchinlkhumbe is automated and collects air temperature, soil surface temperature, atmospheric pressure, humidity, velocity and direction of wind, precipitation (amount and intensity), cloud amount and type, visibility, and snow depth (Battur, 2010). Those data are stored in a database at the National Agency for Meteorology and Environment Monitoring of Mongolia (NAMEM, http://namem.gov.mn/eng/).

\section{Weather/Climate Consideration}

UTSPAA - Storing existing weather data in an accessible format for future comparisons would allow UTSPAA to report documented patterns and characteristics of regional weather.

\section{Water Resources}

According to UTSPAA staff, there is currently no water-quality monitoring in the Darkhad Basin, and there is no water flow-volume monitoring in the basin (Davaatseren Buyanjargal, Ulaan Taiga Specially Protected Areas Administration, oral commun., July 2016). Research efforts possibly have made temporary measures of water quality that could be useful. 
- Any existing water-quality or water-flow data for the Darkhad Basin derived from previous monitoring efforts or previous research could serve as baseline data for future comparisons.

- Storing water quality or water-flow data in an accessible format will make it more available for future comparisons and reporting of patterns and characteristics.

\section{Air Resources}

Atmospheric clarity, also referred to as visibility, is an important aspect of visitor experience. During our visit to the Darkhad Valley (and also Lake Hovsgol) in July 2016, storms were frequent, and visibility was very good to superior. In contrast, we observed significant haze in the Ulaanbataar region on July 8.

According to UTSPA staff, there currently is no air quality monitoring in the Darkhad Basin or the UTSPA, and we are unaware of any air quality studies for the region (Davaatseren Buyanjargal, Ulaan Taiga Specially Protected Areas Administration, oral commun., July 2016).

\section{Air Resources Considerations}

- UTSPAA - Establishing manual, image-based visibility monitoring stations at select ranger stations and UTSPAA headquarters could document visibility and changes over time. Storing visibility data in an accessible format for future comparisons and reporting documented patterns and characteristics of regional visibility could produce a long-term record.

- Gathering existing air-quality data for the Darkhad Basin or nearby comparable areas could provide a basis for comparisons over time.

\section{Spatial Data—Geographic Information System}

\section{Political Boundaries and Infrastructure}

Protected area boundaries, management zones, roads, trails, ranger stations, infrastructure, and political boundaries are important to park management. These data are being incorporated in a GIS for the UTSPAA, and are being developed where necessary, with assistance from the Mongol Ecology Center.

\section{Elevation/Slope/Aspect}

Elevation data are available from the U.S. Geological Survey (USGS) (USGS Global Visualization Viewer or GloVis; glovis.usgs.gov/) at 30-m resolution. From elevation, slope, and aspect, stream delineations, watershed boundaries, and viewsheds (or line-of-sight) can be derived. Elevation, slope, and aspect are among the most frequently used spatial datasets at Yosemite NP and are crucial when stratifying the landscape to determine sampling locations for scientific studies (for example, plant or animal surveys). Elevation, slope, and aspect will be incorporated in the UTSPAA GIS with assistance from the Mongol Ecology Center. 


\section{Geology}

Geology is considered one of the twelve base spatial data layers by the NPS Inventory and Monitoring Program. The surficial geology of the three protected areas is diverse and includes numerous bedrock types, basalt flows, glacial deposits, alluvial deposits, limestone/marble that may contain caves. A geology map can be useful when stratifying the landscape for scientific studies. Geology maps also are useful in identifying geohazards (for example, floodplains, faults and debris flow zones). Surficial geology also contributes to our understanding of soils, geomorphology, landforms, and vegetation and species distribution patterns.

A recent map of the surficial geology of Lake Hovsgol and vicinity is located at the Institute of Geology and Mineral Resources, Mongolian Academy of Sciences (Goulden and others, 2006; p. 6). It may be possible to convert it to a digital version for inclusion in the GIS.

Watersheds, Lakes, and Streams

Lakes and streams are considered one of the 12 base spatial data layers by the NPS Inventory and Monitoring Program. Watershed boundaries can be derived from existing elevation data. Lakes and streams can be mapped or modeled using digital elevation models.

Hydrological data for Mongolia may exist at Rutgers University, but the data also may be available through the Mongolian government. We did not find information on the quality, resolution, and attributes of any hydrological data for the Darkhad Valley and the UTSPA. Should existing digital hydrology data be located, it will be important to assess it for completeness, spatial accuracy, and attribute accuracy. Hydrology data may need to be derived or improved if quality of existing data is suspect or attributes are inadequate.

\section{Fire}

The Mongolian National Emergency Agency records geographic coordinates and radius distance for wildfires within the UTSPAA (Nymgerel Ulzii, Ulaan Taiga Specially Protected Areas Administration, oral commun., 2016). They may have information on source of ignition as well. Sources of ignition in the Ulaan Taiga SPA reportedly include both human activities and lightning (Tumursukh Jal, Director of Ulaan Taiga Specially Protected Areas Administration, oral commun., 2016).

\section{Fire History Considerations}

- Mapping fire perimeters within the UTSPAA could serve to develop a contemporary fire history record, with fires labeled as to ignition source (lightning or anthropogenic) if possible.

- It may be feasible to label fires mapped from imagery with fire severity classes.

- Incorporating records of the National Emergency Agency on fire location and size may be the most cost-effective method for incorporating fire information into the UTSPAA GIS.

- Dendrochronology research within the UTSPAA could serve to develop long-term, fire-history data that would inform management. 
Soils maps document the geographic locations of the various kinds of soils; identify their physical, chemical, and biological properties; and interpret these properties for land-use and facilities planning purposes (for example, roads, sanitary sewerage) (Bauer, 1973). A soils map is considered one of the twelve base spatial data layers by the NPS Inventory and Monitoring Program. Soils can be mapped at different classification levels (for example, soil order, soil series), with different minimum mapping units (for example, 1 ha minimum), and with different attributes (for example, soil depth). However, soils maps at the soil order level generally are not useful for site-specific planning needed for placement of facilities, such as roads.

A soils map for Mongolia is included in the national atlas of the Mongolian People's Republic (Dorzhgotov and Nogina, 1990). A decision on whether and how to incorporate it into the UTSPA GIS would be informed by its spatial resolution, the classification that was used, and whether a translation (to Mongolian or English) has been done or is feasible.

\section{Soils Map Considerations}

- Depending on the needs of the UTSPAA, locating existing digital soils data and assessing that data for completeness, spatial accuracy, and attribute accuracy may be the most cost-effective approach to incorporating soils data in the GIS. Soils data may need to be derived or improved if quality of existing data is suspect or attributes are inadequate.

- Although a soils map is valuable for predicting the occurrence of species, locating facilities, and understanding patterns in productivity, developing a new soils map for the UTSPA may be a lower priority for management than other inventories and base spatial data layers.

\section{Priorities among Inventory Efforts}

The inventories presented here represent variable levels of time investment, technological skill, required capacity, and cost. Some spatial data exist and merely need to be acquired and incorporated in the UTSPAA GIS. In other cases, inventories likely will be implemented only when funding and access to the proper levels of expertise are secured. For these reasons, inventory efforts need not be initiated simultaneously. In the interest of informing inventory planning, we present potential priorities for the various inventory efforts in table 1. 
Table 1. Potential priorities among inventory efforts for the Ulaan Taiga Specially Protected Areas, Hovsgol aimag, northern Mongolia.

\begin{tabular}{|c|c|c|}
\hline Inventory effort & Priority & Rationale \\
\hline Vegetation and land-cover mapping & Medium & $\begin{array}{l}\text { Land-cover classification and mapping across protected } \\
\text { area landscapes provide one of the most essential tools } \\
\text { to biodiversity conservation and management. }\end{array}$ \\
\hline Plant species occurrence & High & $\begin{array}{l}\text { Documents species occurrence and distribution by } \\
\text { protected area with properly designed sampling. }\end{array}$ \\
\hline Animal species occurrence & High & $\begin{array}{l}\text { Documents species occurrence and distribution by } \\
\text { protected area with properly designed sampling. }\end{array}$ \\
\hline Weather-temperature and precipitation & High & $\begin{array}{l}\text { Assembling a long-term weather record tracks patterns in } \\
\text { an important ecological driver. }\end{array}$ \\
\hline Water quality & Medium & $\begin{array}{l}\text { Temperature and sediment transport are relevant to taimen } \\
\text { status and that of all other aquatic life. }\end{array}$ \\
\hline Air quality & Medium & $\begin{array}{l}\text { Visibility monitoring tracks an aspect of visitor } \\
\text { experience. }\end{array}$ \\
\hline Geographic Information System & High & Important resource management tool. \\
\hline Boundaries & High & Available at low to no cost. \\
\hline Elevation, aspect, slope & High & Available at low to no cost. \\
\hline Geology & Medium & Useful in identifying environmental strata and hazards. \\
\hline Hydrology & High & $\begin{array}{l}\text { May already be available. Defines important resource for } \\
\text { wildlife and hydrophytic vegetation. }\end{array}$ \\
\hline Soils & Low & May be done at a coarse scale for lower cost. \\
\hline
\end{tabular}

\section{Monitoring}

\section{Vegetation}

With climate change and changes in land use, there may be changes in vegetation composition and structure resulting from moisture stress, biotic interactions (for example, competition, herbivory), and alterations in fire regime. Changes in patterns of forest mortality (associated with insects, disease, or fire) and changes in vegetation productivity may be indicative of ecosystem change with implications for wildlife habitat and forest health. Each change can be monitored at the landscape scale with remote sensing. However, results may be difficult to interpret, and it may be unclear whether management action is warranted.

Alternatively, monitoring at the plot scale should provide more interpretable results. Establishing a set of monitoring plots with comprehensive data on composition, structure and environmental setting should provide a basis for monitoring vegetation change for one or more plant community types. It will be important for field sites to be permanently marked (for example, with metal rods) and to have highquality location descriptions and coordinates if they are to be useful for monitoring.

To draw conclusions from monitoring efforts with any level of confidence, sampling will need to be done according to a statistical design that incorporates adequate sample size and unbiased spatial distribution to provide for inference at the landscape scale. 


\section{Vegetation Monitoring Considerations}

- Monitoring for vegetation change at the plot scale likely will provide the most precision for detecting changes in structure and composition.

- Basing monitoring on a robust statistical design will minimize sampling bias, allow for estimates of error, and provide for inference at the landscape scale.

\section{Ungulates}

The UTSPAA currently is monitoring the population status of argali and Siberian ibex in Horidal Saridal SPA. Park rangers and staff conduct annual censuses in mid- to late summer. The census duration for each species is about 10 days.

In 2016, estimated population size for argali was about 100 animals divided into two separate groups (Tumursukh Jal, Director of Ulaan Taiga Specially Protected Areas Administration, oral commun., 2016). Summer habitat includes rolling to hilly grassland steppe with little to no tree cover. In mid- to late winter, argali move to low-elevation grasslands where they overlap with the winter range of domestic grazing animals for about 20 days. Forage availability at these locations is limited and there may be competition between the argali and domestic animals (Tumursukh Jal, Director of Ulaan Taiga Specially Protected Areas Administration, oral commun., 2016). Poaching is thought to be a significant source of mortality. Disease transmission from domestic livestock does not seem to be an issue (Tumursukh Jal, Director of Ulaan Taiga Specially Protected Areas Administration, oral commun., 2016).

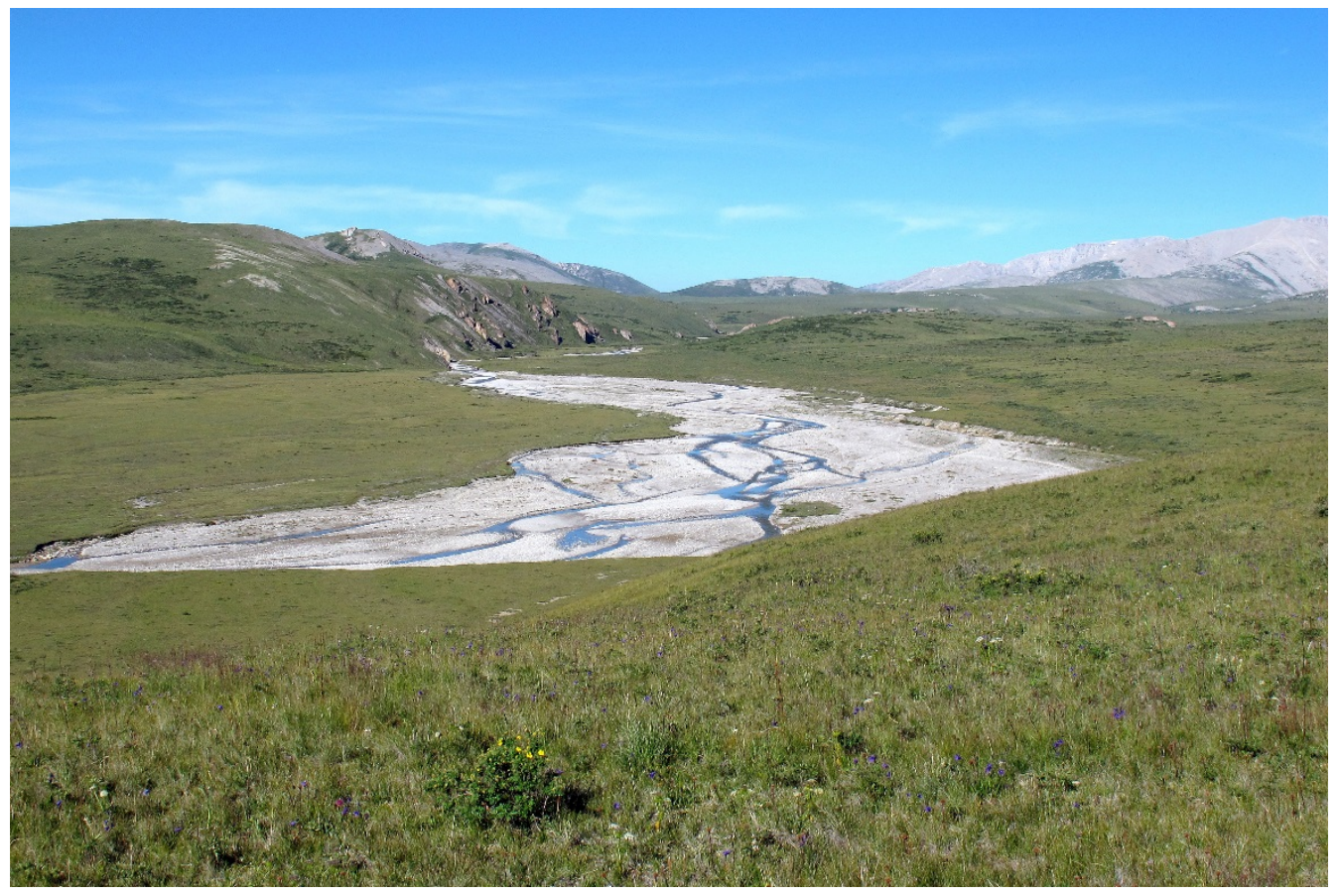

Figure 3. Photograph showing argali habitat within Horidol Saridag Strictly Protected Area, Hovsgol aimag, northern Mongolia, July 2016. 
The ibex population is estimated to include about 300 animals and seems to be increasing. The kid-to-nanny ratio in 2015 was 1.81 to 1 (Tumursukh Jal, Director of Ulaan Taiga Specially Protected Areas Administration, oral commun., 2016). In 2016, the population included about 70 adult females. Ibex move seasonally between cool summer ranges and warm winter ranges. They generally inhabit high-elevation sites characterized by steep, rocky terrain.

\section{Ungulate Monitoring Considerations}

- UTSPAA - Continuing annual population censuses, particularly for argali, will provide a basis for detecting response to management actions.

- Important demographic data to collect during censuses includes:

- Population count by sex and age class (age is estimated by counting horn rings);

- Lamb-to-ewe and kid-to-nanny ratios for argali and ibex, respectively;

- Age-specific survival rate by age class (calculated using [(Xt -Xt+1)/Xt], where $\mathrm{X}=$ population size and $\mathrm{t}=$ time in years);

- Adult female population size (females $>2$ years old); and

- Sources of mortality, if available.

\section{Siberian Taimen}

On the basis of sein surveys, taimen are declining. This is supported by their national listing status as endangered. With continuing threats of poaching and climate change, it is important to monitor the status of the taimen in protected areas of Mongolia.

\section{Taimen Monitoring Considerations}

Identifying methods for monitoring the status of taimen ideally will consider bias, precision, and the use of standardized sampling methods.

\section{Weather}

The two weather stations at Ulaan Uul and Renchinlkhumbe provide a 40-year record of temperature and precipitation that will prove valuable for relating resource conditions to climate and for comparisons over time. An analysis of trends at Renchinlkhumbe and two station at Lake Hovsgol indicated a warming trend for the period with increases in the number of hot days and warm nights and a decrease in the number of cold days and cold nights (Nandintsetseg and others, 2007). Although these stations provide a valuable ongoing record, they do not capture the variability of weather conditions across the elevational gradient of the three protected areas because of the limited elevation range of the stations, distance from the protected areas, and the influence of elevation and mountain topography on weather. Additional weather stations deployed at appropriate sites at higher elevations could capture more of this variability.

Although ranger stations located within the boundaries of protected areas seem to be logical locations for weather stations, there are some challenges to placing and maintaining weather stations at these sites. Ranger stations of the three protected areas tend to be at low elevations near access points from the Darkhad Valley and may simply duplicate weather information from Ulaan Uul and Renchinlkhumbe. The eastern entrance of Horidol Saridag SPA does not have a ranger station, and unattended equipment in the valley often is stolen or vandalized. However, ranger stations generally are occupied each night throughout the year, and that could provide a consistent presence for data collection and maintenance. 
Manual weather measurements are useful for quality control. They also may be most useful when precipitation is in the form of snow, and they may be the only feasible measurement method in some areas. For unstaffed or infrequently staffed areas, automated weather stations may be the best option. A fully instrumented and pre-programmed weather station is available from Davis Instruments (www.davisnet.com). The Wireless Vantage Pro $2^{\mathrm{TM}}$ weather station (USD1,295) includes a rain collector, temperature and humidity sensors, and anemometer for wind speed. A 12-volt battery and solar panel would be required to power the weather station. A manual rain gauge and lightning protection often are recommended. The total cost would be about USD2,000.

Once general locations for weather stations have been identified, a suitable site must be identified to ensure quality data are collected. Campbell Scientific has developed guidelines for siting of weather stations that may be helpful in microsite selection (Campbell Scientific, 1997).

\section{Weather Monitoring Consideration}

A more detailed understanding of weather and climate patterns could be informed by additional weather stations in the Darkhad Basin along an elevational gradient in the mountains east (that is, Horidal Saridag SPA) and west (that is, Ulaan Taiga SPA or Tengis-Shishged NP) of the Darkhad Valley. These weather stations likely will need to be automated.

\section{Water Quality}

The high energy and highly dynamic streams of the Darkhad Valley make automated stream flow measurements difficult - the streams tend to be braided and seem to change course frequently. Although gauging station data to quantify stream flow volume are collected by the Mongolian government, there are no gauging stations in the Darkhad Basin.

Water temperature may be an important factor in the management of taimen, particularly in relation to spawning habitat. Water temperature sensors generally are automated, can operate for long periods of time, and can be hidden or submerged in a stream (or any water body). Sediment load also may be an important parameter to monitor, because it may affect taimen spawning habitat.

Although the Secchi disk method does not document factors limiting water clarity (for example, dissolved substance, phytoplankton, and suspended particles), it is one of the most common, affordable, and easy-to-use pieces of equipment used to measure water clarity.

\section{Water-Quality Monitoring Considerations}

Monitoring water temperature using automated sensors and water clarity using the Secchi disk could be located in rivers where Siberian taimen are present.

\section{Air Quality}

Visibility is monitored at Yosemite NP and many other U.S. national parks through the IMPROVE program (www.nature.nps.gov/air/monitoring/vismon.cfm) using automated cameras to capture relative, qualitative changes in visibility in selected views. The images can be analyzed to determine visual range (that is, the distance of the farthest object visible in the image).

\section{Air-Quality Monitoring Considerations}

The UTSPAA headquarters and ranger stations offer locations at which staff could establish visibility monitoring of selected peaks of Horidol Saridag SPA. 


\section{Research to Inform Natural Resource Inventory and Monitoring}

\section{Rare Plant Status}

Over 40 species on the Mongolian red list are known to occur in northern Hovsgol (Nyambayar and others, 2011). Additional information on the distribution and abundance of those determined to be highest priority would provide a basis for management and protection. Research that would inform future monitoring also might include determining species habitat requirements and implementing demographic studies to quantify population sizes and rates of plant reproduction, survival, and growth. Matrix population models are useful in projections of how plant populations react to climate change and other environmental threats.

\section{Fire History}

Lightning-ignited fire may be an important driver of vegetation structure and composition at least in the forest-steppe zone. Fire frequency and intensity may increase with climate change, so understanding historical patterns and how patterns may have changed more recently (for example, with increased anthropogenic activity in forests) will be important for making decisions about fire and vegetation management. An investigation of long-term fire history using dendrochronology could provide information on historical fire frequency and extent in relation to climate patterns. With the resulting information on the historical fire regime by vegetation type, including the normative time between fires (that is, fire return interval), managers can better interpret current fire behavior and its likely effects on resources. This also will better inform managers if they address increases in humancaused fires.

\section{Ungulates}

Determining home range and movement patterns for argali and Siberian ibex would inform management. An investigation of seasonal grazing competition between argali sheep and domestic stock on winter range would inform both managers and stakeholders.

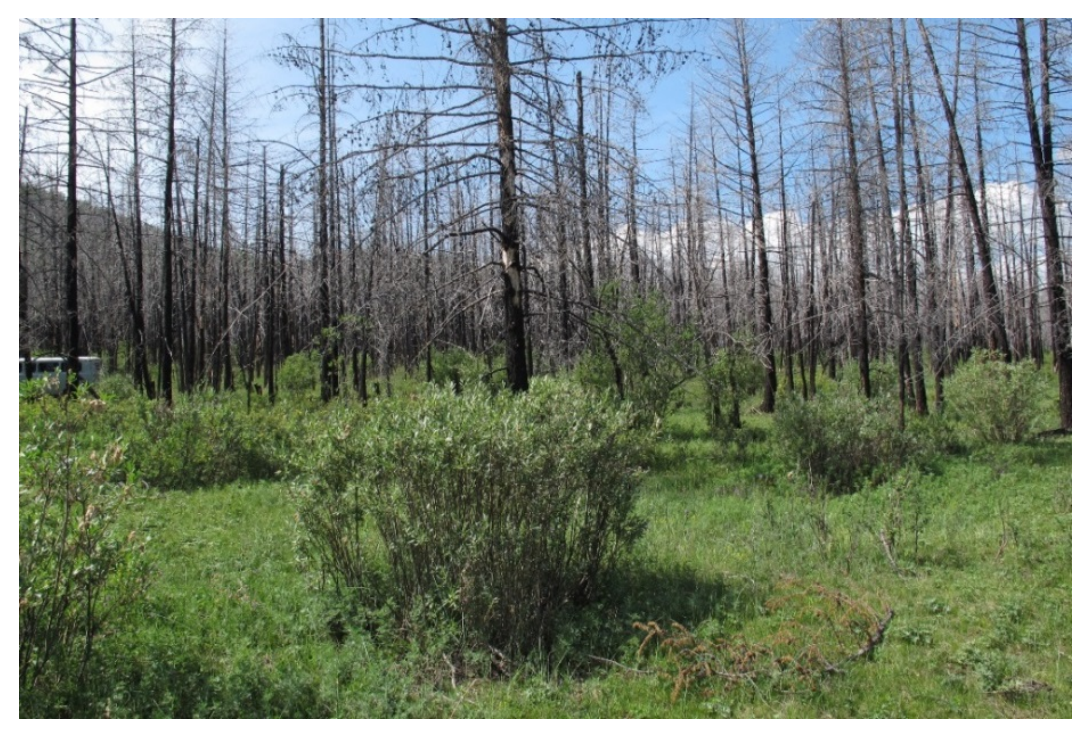

Figure 4. Photograph showing high-severity burn and recovery of shrub and herbaceous species after 7 years, Tengis-Shishged National Park, Hovsgol aimag, northern Mongolia, July 2016. 


\section{Conclusions}

The Ulaan Taiga Specially Protected Areas (UTSPA) were established to protect many special natural and cultural resources in northern Hovsgol. Providing a compilation and summary of available and relevant scientific literature to Ulaan Taiga Specially Protected Areas Administration (UTSPAA) staff would assist them in resource management and protection activities. Additionally, a vegetation map developed to meet the needs of the UTSPAA would inform wildlife management (for example, quantifying and modeling habitat), fire management (for example, fuel structure), resource protection, and scientific efforts.

Work accomplished as part of the joint Russian-Mongolian expeditions, the joint GermanMongolian efforts, and other work exhibits potential for having produced curated specimens or published work documenting the vascular flora of the UTSPA. If or when records for curated specimens can be obtained, remaining data gaps on species occurrence and distribution may be addressed most effectively with field surveys.

Scientific surveys of the past also may help populate terrestrial vertebrate species lists for the UTSPA. Mongolian and German institutions and the Russian Academy of Sciences appear to be the most likely repositories of curated specimens from the UTSPA. Until records are obtained, ranger observations are serving to build species lists by protected area for both plants and animals.

Air quality, water quality, and weather monitoring could produce datasets useful in interpreting changes in natural resource status. Storing these data in well-designed, accessible formats would make them more available for future analysis. Similarly, a geographic information system, developed for the UTSPA with support from the Mongol Ecology Center, could be an important tool in the management of natural resources and support of scientific efforts.

The UTSPAA currently monitors argali (Ovis ammon) and Siberian ibex (Capra sibirica) populations; we simply suggest some additional demographic data that would allow them to determine survivorship and identify sources of mortality. Adding vegetation and taimen monitoring may present a challenge with current capacities, but we identify monitoring efforts that we believe would be most important should capacity allow.

Among potential subjects of future research, drivers of ecosystem change, such as forest fire extent and severity, and resources of special management concern, such as rare species, could assist UTSPAA with identifying resource management objectives. Although UTSPAA staff manage protected areas in one of the most remote regions of the world, they are engaged in collaborations with national, international, and foreign entities (for example, the National Park Service in the United States), thereby expanding their capacity to protect these world-class landscapes.

\section{References Cited}

Batbaatar, J., and Gillespie, A.R., 2015, Outburst floods of the Maly Yenisei-Part I-Review: International Geology Review, p. 1-30, doi:10.1080/00206814.2015.1114908.

Batbaatar, J., and Gillespie, A.R., 2016, Outburst floods of the Maly Yenisei-Part II-New age constraints from the Darhad Basin: International Geology Review, p. 1-27, doi:10.1080/00206814.2016.1193452.

Batima, P., Natsagdorj, L., Gombluudev, P., and Erdenetsetseg, B., 2005, Observed climate change in Mongolia: Assessments of impacts and adaptations of climate change workings papers, AIACC Working Paper No. 12, p. 1-26.

Batsaikahn, N., Samiya, R., Shar, S., Lkhagvasuren, D., and King, S.R.B., 2014, A field guide to the mammals of Mongolia ( $2 \mathrm{~d}$ ed.): London, Zoological Society of London, 307 p. 
Battur, N., 2010, Observation network of Mongolia, Presented at Japan Meteorological Agency/World Meteorological Organization Workshop on Quality Management in Surface, Climate and Upper-air Observations in RA II (Asia), Tokyo, Japan, July 27-30, 2010: National Agency for Meteorology and Environment Monitoring of Mongolia, 5. p. [Also available at http://www.jma.go.jp/jma/en/Activities/qmws_2010/CountryReport/CS403_Norov_Battur(Mongolia).pdf.

Bauer, K.W., 1973, The use of soils data in regional planning: Geoderma, v. $\overline{10}$, nos. $\overline{1}-2$, p. 1-26.

Campbell Scientific, 1997, Weather station siting and installation tools-Application note code 4-S: Logan, Utah, Campbell Scientific, Inc., accessed July, 20 2016, at https://s.campbellsci.com/documents/sp/technical-papers/siting.pdf.

Clark, E.L., Munkhbat, J., Dulamtseren, S., Baillie, J.E.M., Batsaikhan, N., Samiya, R., and Stubbe, M., comps. and eds., 2006, Mongolian red list of mammals - Regional red list series-Vol. 1: London Zoological Society of London. [Also available at http://library.zsl.org.] [In English and Mongolian.] Dorzhgotov, D., and Nogina, N. A., 1990, Khors (The soil map of Mongolia) in Orshikh, N., Morgunova, N.A., and Rodionov, M.N., eds., Bügd Nairamdakh Mongol ArdUls, Undesnii Atlas (National Atlas of the Mongolian People's Republic): Ulaanbaatar, Mongolia, BNMAU-yn Shinzhlekh Ukhaany Akad., p. 6667. [In Russian.]

Faber-Langendoen, D., Keeler-Wolf, T., Meidinger, D., Tart, B., Hoagland, C., Josse, G., Navarro, S., Ponomarenko, Saucier, J.-P., Weakley, A., and Comer, P., 2014, EcoVeg-A new approach to vegetation description and classification: Ecological Monographs, v. 84, no. 4, p. 533-561.

Federal Geographic Data Committee, 2008, National vegetation classification standard version 2.0: Reston, Virginia, Federal Geographic Data Committee, Vegetation Subcommittee, FGDC-STD-005-2008, 126 p. Gillespie, A.R., Burke, R.M., Komatsu, G., and Bayasgalan, A., 2008, Late Pleistocene glacier in Darhad Basin, northern Mongolia: Quaternary Research, v. 69, p. 169-187, doi: 10.1016/j.yqres.2008.01.001. Gombobaatar, S., and Monks, E.M., comps., and Seidler, R., Sumiya, D., Tseveenmyadag, N., Bayarkhuu, S., Baillie, J.E.M., Boldbaatar, Sh., Uuganbayar, Ch., eds., 2011, Birds_-Regional red list series_Vol.7: London and Ulaanbaatar, Mongolia, Zoological Society of London, National University of Mongolia, and Mongolian Ornithological Society. 1,036 p. [In English and Mongolian.]

Goulden, C.E., Tumurtogoo, O., Karabanov, E., and Mongontsetseg, A., 2006, The geological history and geography of Lake Hovsgol in Goulden, C.E., Sitnikova, T., Gelhous, J., and Boldgiv, B., eds., The geology, biodiversity, and ecology of Lake Hovsgol (Mongolia): Leiden, The Netherlands, Backhuys Publishers, p. 1-19.

Grinnell, J., and Storer, T.I., 1924, Animal life in the Yosemite-An account of the mammals, birds, reptiles, and amphibians in a cross-section of the Sierra Nevada: Berkeley, University of California Press, 752 p., doi: http://dx.doi.org/10.5962/bhl.title.32895.

Grubov, V.I., 1982, Key to the vascular plants of Mongolia (with an atlas)—Vols. I and II: Leningrad, Nauka, 443 p.

Gubanov, I.A., 1996, Conspectus of the flora of outer Mongolia: Moscow, Valang Press, 136 p.

Heggem, E.S.F., Etzelmuller, B., Anarmaa, S., Sharkhuu, N., Goulden, C.E., and Nandintsetseg, B., 2006, Spatial distribution of ground surface temperatures and active layer depths in the Hovsgol area, northern Mongolia: Permafrost and Periglacial Processes, v. 17, p. 357-369, doi: 10.1002/ppp.568.

Hessl, A., Ariya, U., Brown, P., Byambasuren, O., Green, T., Jacoby, G., Sutherland, E.K., Nachin, B., Maxwell, R.S., Pederson, N., De Grandpré, L., Saladyga, T., and Tardif, J.C., 2012, Reconstructing fire history in central Mongolia from tree-rings: International Journal of Wildland Fire, v. 21, p. 86-92, doi: http://dx.doi.org/10.1071/WF10108.

Hilbig, W., 1995, The vegetation of Mongolia: Amsterdam, SPB Academic Publishing, 258 p.

Hilbig, W., 2000, Annotated outline of the plant communities and their higher syntaxa in Mongolia: Feddes Repertorium, v. 111, nos. 1-2, p. 75-120. 
Hooper, D.U., Chapin, F.S., III, Ewel, J.J., Hector, A., Inchausti, P., Lavorel, S., Lawton, J.H., Lodge, D.M., Loreau, M., Naeem, S., Schmid, B., Setala, H., Symstad, A.J., Vandermeer, J., and Wardle, D.A., 2005, Effects of biodiversity on ecosystem functioning-A consensus of current knowledge: Ecological Monographs, v. 75, no. 1, p. 3-35, http://www.jstor.org/stable/4539083.

International Union for the Conservation of Nature, 2016, Species mapping tool: National Red List Web site, accessed August 6, 2016, at www.nationalredlist.org/support-information/tools-red-lists/tools/.

Ivanova, G.A., Ivanov, V.A., Kukavskaya, E.A., and Soja, A.J., 2010, The frequency of forest fires in Scots pine stands of Tuva, Russia: Environmental Research Letters, v. 5, no. 1, p. 015002, doi:10.1088/17489326/5/1/015002.

Jennings, M.D., Faber-Langendoen, D., Loucks, O.L., Peet, R.K., and Roberts, D., 2009, Standards for associations and alliances of the U.S. National Vegetation Classification: Ecological Monographs, v. 79, no. 2, p. 173-199.

Kottelat, M., 2006, Fishes of Mongolia-A check-list of the fishes known to occur in Mongolia with comments on systematics and nomenclature: Washington, D.C., The World Bank, 103 p.

Logatchev, N.A., and Florensov, N.A., 1978, The Baikal system of rift valleys, in Logatchev, N.A., and Mohr, P.A., eds., Geodynamics of the Baikal Rift Zone: Tectonophysics, v. 45, p. 1-13.

Markon, C.J., and Wesser, S., 2000, Land cover mapping of the National Park Service northwest Alaska management area using Landsat multispectral and thematic mapper satellite data: U.S. Geological Survey Open-File Report 2000-51, 45 p. [Also available at

https://irma.nps.gov/DataStore/Reference/Profile/167945.]

Moritz, C., Patton, J.L., Conroy, C.J., Leache, A., Rush, A., and Beissinger, S.R., 2011, A re-survey of the Grinnell-Storer vertebrate transect through Yosemite National Park, California: Natural Resource Technical Report NPS/SIEN/NRTR-2011/439, National Park Service, Fort Collins, Colorado, 133 p.

Moritz, C., Patton, J., Conroy, C., Parra, J., White, G., and Beissinger, S., 2008, Impact of a century of climate change on small-mammal communities in Yosemite National Park, USA: Science, v. 322, p. 258261, doi:10.1126/science.1163428.

Maroney, R.L., 2005, Conservation of argali Ovis ammon in western Mongolia and the Altai-Sayan: Biological Conservation, v. 121, p. 231-241.

Myers, N., 1996, Environmental services of biodiversity: Proceedings of the National Academy of Sciences of the United States of America, v. 93, p. 2,764-2,769.

Namkhaijantsan, G., 2006, Climate and climate change of the Hövsgöl region, in Goulden, C.E., Sitnikova, T., Gelhaus, J., and Boldgiv, B., eds., The geology, biodiversity and ecology of Lake Hovsgol (Mongolia): Leiden, The Netherlands, Backhuys Publishers p. 63-76.

Nandintsetseg, B., Greene, J.S., and Goulden, C.E., 2007, Trends in extreme daily precipitation and temperature near Lake Hovsgol, Mongolia: International Journal of Climatology, v. 27, p. 341-347, doi:10.1002/joc. 1404.

National Agency for Meteorology, Hydrology, and Environmental Monitoring, 2016, Historical temperature and precipitation data, 1975-2015: Moron Branch, Moron, Khuvsgul aimag, Mongolia, National Agency for Meteorology, Hydrology, and Environmental Monitoring Web site, accessed July 20, 2016, at www.icc.mn/aimag/Khuvsgul/. [In Mongolian.]

National Park Service, 2009, Strategic plan for natural resource inventories-FY 2008-FY 2012: National Park Service, Fort Collins, Colorado Natural Resource Report NPS/NRPC/NRR—2009/094.

NatureServe, 2016a, U.S. National Vegetation Classification Hierarchy Explorer: U.S. National Vegetation Classification Hierarchy Explorer Web site, accessed September 21, 2016, at http://usnvc.org/exploreclassification/.

NatureServe, 2016b, NatureServe explorer-Ecological classifications: NatureServe Web site, accessed July 21, 2016, at http://explorer.natureserve.org/classeco.htm\#iVegetationClass. 
Nishida, H., and Jamsran, T., eds., 2009, Darhadyn Wetland in Mongolia—Synthesis investigation on Ecosystems: Ishikawa, Japan, NPO Mongolia Ecology Information Center, 539 p.

Nyambayar, D., Oyuntsetseg, B., and Tungalag, R., comps., and Jamsran, Ts., Sanchir, Ch., Bachman, S., Soninkhishig, N., Gombobaatar, S., Baillie, J.E.M., and Tsendeekhuu, Ts., eds., 2011, Plants (Part 1), Mongolian red list and conservation action plans of plants - Regional red list series-Vol. 9: London and Ulaanbaatar, Mongolia, National University of Mongolia and Zoological Society of London, 183 p. [Also available at www.nationalredlist.org.]

Nyamjav, B., Goldammer, J.G., and Uibrig, H., 2007, The fire situation in Mongolia: International Forest Fire News, v. 36, p. 46-66. [Also available at http://www.fire.uni-freiburg.de/iffn/iffn_36/content36.htm.] Ocock, J., Baasanjav, G., Baillie, J. E. M., Erdenebat, M., Kottelat, M., Mendsaikhan, B., and Smith, K., eds., 2006, Mongolian red list of fishes-Regional red list series_-Vol. 3: London and Ulaanbaatar, Mongolia, Zoological Society of London, 68 p. [Also available at www.nationalredlist.org.]

Park, Y.D., Lee, D.K., Tsogtbaatar, J., and Stanturf, J.A., 2010, Effects of forest fire and logging on forest degradation in Mongolia in Stanturf, J.A., ed., Proceedings of the 14th Biennial Southern Silvicultural Research Conference, February 26-March 1, 2007, Asheville, North Carolina: U.S. Department of Agriculture, Forest Service, Southern Research Station, General Technical Report SRS-121, p. 571-575.

Patton, J.L., 2006, Final report-Inventory and monitoring program-The Grinnell re-survey project, Yosemite National Park: National Park Service, Berkeley, California, Task agreement J8C07040003, 48 p. [Also available at https://irma.nps.gov/DataStore/Reference/Profile/2204131.]

Ralph, C.J., Sauer, J.R., and Droege, S., technical eds., 1995, Monitoring bird populations by point counts: U.S. Forest Service, Pacific Southwest Research Station, Albany, California, General Technical Report PSW-GTR-149, 187 p. [Also available at www.fs.fed.us/psw/publications/documents/psw_gtr149/psw_gtr149.pdf.]

Sharkhuu, A., Sharkhuu, N., Etzelmuller, B., Heggem, E.S.F., Nelson, F.E., Shiklomanov, N.I., Goulden, C.E., and Brown, J., 2007, Permafrost monitoring in the Hovsgol mountain region, Mongolia: Journal of Geophysical Research, v. 112, no. F02S06, doi: 10.1029/2006JF000543.

Terbish, Kh., Munkhbayar, Kh., Clark, E.L., Munkhbat, J., Monks, E.M., Munkhbaatar, M., Baillie, J. E.M., Borkin, L., Batsaikhan, N., Samiya, R. and Semenov, D.V., comps. and eds., 2006, Mongolian red list of reptiles and amphibians - Regional red list series_-Vol. 5: London and Ulaanbaatar, Mongolia, Zoological Society of London, 68 p. [In English and Mongolian.]

Tsogtbaatar, J., 2004, Deforestation and reforestation needs in Mongolia: Forest Ecology and Management, v. 201, no. 1, p. 57-63, doi: 10.1016/j.foreco.2004.06.011.

University of Greifswald, 2010 (continuously updated), FloraGREIF_-Virtual flora of Mongolia: Greifswald, Germany, Computer Centre of University of Greifswald, Institute of Botany and Landscape Ecology, Institute of Geography and Geology, D-17487 Greifswald, Germany, Web page, accessed September 14, 2016, at http://greif.uni-greifswald.de/floragreif/.

Urgamal, M., Oyuntsetseg, B., Nyambayar, D., and Dulamsuren, Ch., 2014, Conspectus of the vascular plants of Mongolia: Ulaanbaatar, Mongolia, Admon Press, 282 p.

Valendik, E.N., Ivanova, G.A., Chuluunbator, Z.O., and Goldammer, J.G., 1998, Fire in forest ecosystems of Mongolia: International Forest Fire News, v. 19, p. 58-63. [Also available at www.fire.unifreiburg.de/iffn/country/mn/mn_5.htm.]

von Wehrden, H., Wesche, K., Miehe, G., and Reudenbach, C., 2006, Vegetation mapping in central Asian dry eco-systems using Landsat ETM-A case study on the Gobi Gurvan Sayhan National Park: Erdkunde v. 60 , no. 3 , p. 261-272, doi: 10.1007/s12224-009-9042-0. 


\section{Additional References}

Krivonogov, S.K., Sheinkman, V.S., Mistruykov, A.A., 2005, Stages in the development of the Darhad dammed lake (northern Mongolia) during the Late Pleistocene and Holocene: Quaternary International, v. 136, p. 83-94.

Krivonogov, S.K., Yi, S., Kashiwaya, K., Kim, J.C., Narantsetseg, T., Oyunchimeg, T., Safonova, I.Y., Kazansky, A.Y., Sitnikova, T., Kim, J.Y., and Hasebe, N., 2012, Solved and unsolved problems of sedimentation, glaciation, and paleolakes of the Darhad Basin, northern Mongolia: Quaternary Science Reviews, v. 56, p. 142-163.

National Research Council, 2014, Opportunities to use remote sensing in understanding permafrost and related ecological characteristics - Report of a workshop: Washington, D.C., The National Academies Press, 84 p., doi: 10.17226/18711. 


\section{Glossary}

Aimag Country subdivision approximately comparable to a province.

Dendrochronology Method of dating tree rings to identify climate patterns occurring when rings were formed.

Dichotomous key A tool, in the form of a series of binary choices, that lead the user to the name of an organism.

GIS A geographic information system is a combination of electronic spatial data (that is, maps) and software used to store and query representations of landscape features. Datasets may take the form of lines (that is, vector data such as roads or trails), areas (polygons representing subject classes, for example, vegetation types), or grids (with cells having values that may or may not differ from adjacent cells, for example, elevation, satellite imagery).

Georeference The process of associating a map or image with a physical location.

Gol River.

Hydrophytic Water loving.

Phytogeographic Related to the geographic distribution of plant species.

Soum Country subdivision approximately comparable to a county level of organization within aimags.

Steppe Grassland, generally.

Visibility The distance at which objects can be seen as affected by pollutants or moisture in the air. 


\section{Appendix 1. Considerations Regarding Land-Cover Type Classification and Mapping for the Ulaan Taiga Specially Protected Areas}

Before a classified satellite image can be labeled during the mapping process, there must be a defined set of vegetation or land-cover types. In the absence of pre-existing classification work for an area, sampling across environmental gradients is the most efficient approach for capturing the various vegetation and land-cover types supported by various environmental settings. Vegetation and land-cover are expressions of environmental settings, including climate, landform, soils, and geology. Sampling across physical and geographical strata might include unique combinations of elevation zone, surficial geology, precipitation, and perhaps fire history to capture the various floristic (that is, species composition) and physiognomic (that is, growth form) types (see NatureServe, 2016a, for examples).

Field sampling is an important aspect of land-cover classification and mapping, and it serves multiple purposes. Sufficient samples collected from within landscape strata (for example, elevation zones, aspect classes, geologic substrates, soil depths) serve to inform detailed descriptions of mapping classes. They also serve as ground verification points for remotely sensed imagery that will form the basis for the map. Some of the samples (plots) can be withheld from the classification and used to assess map accuracy. Finally, accurate and detailed samples can serve as the basis for a more finely resolved floristic classification in the future if needed (that is, lower levels of the classification hierarchy). For example, future needs may require more detailed mapping for parts of protected areas detailing specific dominant or diagnostic species in the overstory and understory layers. An example of such a class might be Siberian larch (Larix sibirica)-Siberian pine (Pinus sibirica)/round-leaved dwarf birch (Betula rotundifolia)-Lapland azalea (Rhododendron lapponicum) where the first two species are overstory dominants and the second two species are understory dominants.

Once unbiased sampling locations are derived across environmental strata, sampling would involve field visits to collect detailed information from plots of specified size and shape (for example, 0.1-ha rectangle). Details likely will include geographic location (that is, place name, coordinates), topographic setting (elevation, slope, aspect, slope position), substrate (for example, geologic type, soil texture), and vegetation composition and structure (for example, abundance by species for all vegetation layers).

We suggest classification follow established standards for data collection, analysis, and type description (NatureServe, 2016b). Faber-Langendoen and others (2014) and Jennings and others (2009) provide the best available guidance for classifying vegetation and land cover in the structure of the International Vegetation Classification (IVC). The hierarchical nature of the IVC provides opportunities to classify and map land cover at an appropriate level in the hierarchy for the scale and resolution of the intended map. For example, for a protected area less than 100,000 ha, it is feasible to map at the lowest levels of the hierarchy (for example, alliance such as Douglas-fir-white fir woodland) where types are defined based on dominant or diagnostic species and local ecological settings. For the Ulaan Taiga Specially Protected Areas (SPA), mapping classes at the middle level in the hierarchy (for example, macrogroup such as southern Rocky Mountain lower montane forest, which includes types with specific dominant conifer species) may be more practicable. That would focus the classification on differences in plant growth form, groups of diagnostic species, and broad ecological settings rather than fine-scale differences in dominant species, which would be more costly. 
Alternatively, existing classifications that describe vegetation types occurring in the specially protected areas could be applied to the Ulaan Taiga SPA (for example, Hilbig 2000). As indicated earlier in this appendix, field samples (plots) would then serve to verify the presence and location of applicable classes and to provide details on local expression of classes. Additional classes could be derived from sample analysis, as needed.

Mapping classes for larger landscapes commonly are between the formation (plant growth form) and alliance (dominant species) levels in the hierarchical IVC (for example, closed needleleaf forest mapping class representing white spruce and black spruce is between needleleaf forest formation and white spruce and black spruce alliances). For the Ulaan Taiga Specially Protected Areas, the most efficient and appropriate classification level may be in the middle level of the IVC hierarchy such as the Macrogroup (NatureServe, 2016b). The Macrogroup is defined as "combinations of [medium-sized] sets of diagnostic plant species and diagnostic growth forms that reflect...differences in composition and...regional differences in mesoclimate, geology, substrates, hydrology, and disturbance regimes" (NatureServe, 2016b). An example is Southern Rocky Mountain Lower Montane Forest, which is characterized by Douglas-fir, white fir, Colorado blue spruce, and ponderosa pine. 


\section{Appendix 2. Considerations for Documenting Plant Species Occurrence}

\section{Existing Documentation}

\section{Herbarium Holdings}

Herbarium specimens are the most reliable evidence of species occurrence within protected areas. They provide material for verifying species identification and for later determination should taxonomic understanding evolve to separate or combine taxa. If herbarium specimens are from recent decades, they would likely already include sufficient specificity on location to identify those from protected areas. Those from earlier decades with imprecise locations can reduce confidence that they originated within protected areas, but they can be labeled to that effect in a database.

Preliminary online searches indicated relatively few collections from Mongolia at U.S. and British institutions (368 specimens altogether from Missouri Botanical Garden; The New York Botanical Garden; Gray Herbarium; British Natural History Museum; and Royal Botanic Gardens, Kew). However, the Herbarium of the National University, Mongolian Academy Sciences has 100,000 specimens, Martin Luther University of Halle-Wittenberg has 12,500 specimens (1,698 taxa), and Moscow University Herbarium has 27,410 specimens. A brief review indicated that the northern part of Hovsgol aimag is undercollected; however, specimen records might be more carefully reviewed to locate those from the Ulaan Taiga Specially Protected Areas (UTSPA).

Searches of online records can be done on a geographic basis using specimen location maps displayed in FloraGRIEF, or it may be possible to use vector files of protected area boundaries to query specimen records and identify those within UTSPA boundaries with assistance from FloraGREIF managers. Another way of locating specimens may be through publications that cite specimens submitted to herbaria. Publications summarizing floristic patterns may provide leads to specimen records (for example, Urgamal and others, 2014).

Online searches may be informed by the construction of potential species lists based on species distributions. Sources of species distributions include distribution maps in FloraGRIEF and distribution descriptions in published floras.

Finally, direct inquiries of herbaria can be productive if holdings are not available online and if holdings of particular taxa expected in protected areas can be reviewed to check collection localities. Authors who have evaluated existing collections may be a good source of records (for example, Urgamal and others, 2014).

\section{Published Accounts}

Credible publications that provide detailed data on species occurrence also can be sources of evidence for species occurrence. Detailed reviews should indicate whether information is sufficient for use as evidence. Criteria for whether observations are acceptable may include the credentials of the observer, taxonomic precision (that is, reported at the species or subspecific level and not limited to the genus level), and precision of reported localities so it can be determined whether reports originate from within protected areas. 


\section{Photographic Evidence}

High-quality georeferenced photographs also can be used to document species occurrence within protected areas. Minimum documentation to accompany photographs ideally would include photographer, date, location name, latitude, and longitude. Photographs ideally would include the entire plant and reproductive structures (for example, flowers or fruits as available). It is best to retain exchangeable image file format (that is, Exif) data that are stored in digital images because they contain date, file size, shutter speed, f-stop, and other image documentation.

\section{New Specimen Collections}

Once existing documentation of species occurrence is gathered, collecting additional specimens will (1) expand the species list, and (2) further the understanding of species distributions. It may be most efficient to collect new specimens during sampling for other purposes such as the land-cover mapping effort. That is, while sampling vegetation plots for building the land-cover classification, field biologists could collect quality plant specimens and detailed data for herbarium labels that will be cited as evidence of species occurrence. The advantages are as follows: (1) sampling will be stratified across abiotic environmental factors, (2) the field sampling can serve multiple purposes, and (3) plot data will provide much of the information needed for herbarium specimen labeling.

\section{Specimen and Species List Data}

Data on species occurrence are best stored in a data structure that allows full specimen records and attribute data to be linked to a species list. We suggest specimen record entries include taxon with authority, collector, collection number (assigned by collector), date, location name, location coordinate, habitat, associated species, specimen description if appropriate (for example, flower color, height), institution, and accession number. Species list entries may include taxon name and authority, taxon name without authority, plant family, order, status in protected area (for example, present, and historical occurrence), native/non-native status, number of evidence records (that is, vouchers, published sources, or photographs), and, optionally, group (for example, gymnosperm, dicot, monocot), duration (annual, perennial), and growth form. 


\section{Appendix 3. Considerations for Documenting Faunal Species Occurrence}

There is utility in compiling preliminary species lists for the UTSPA based on distribution maps. Expected species lists can inform management and survey planning. The Species Mapping Tool on the International Union for the Conservation of Nature National Red List Web page (www.nationalredlist.org/support-information/tools-red-lists/tools/) will generate species lists based on location input. This tool produces a list of fish, amphibians, reptiles, and mammals (birds are not yet available) based on distribution maps in the Mongolian Biodiversity Databank. However, these lists are based on predicted species occurrence and must be validated by voucher specimens or other acceptable documentation. This can be accomplished by locating existing specimens at curated institutions or conducting field surveys. Preliminary searches of online vertebrate specimen records (for example, VertNet, http://vertnet.org/) yielded few records for the Hovsgol mountain region. A more exhaustive search for specimens housed at institutions, especially those in Russia, which are not on VertNet, is warranted but beyond the scope of this document.

\section{Field Surveys}

For field survey methods, a good option would be to use Grinnell-style surveys (Grinnell and Storer, 1924; Moritz and others, 2008, 2011) with minor modifications in sampling site selection to ensure that they are statistically robust and can form the basis for long-term monitoring. Although a Grinnell-style survey primarily is intended to detect vertebrate species, it could be modified with relative ease to include either opportunistic or systematic sampling for invertebrates. We estimate that a survey for an area the size of Tengis-Shishged National Park would require about three field seasons to complete.

The Grinnell style survey generally involves establishing a series of base camps along an elevational transect. The intent is to capture the broadest range of available habitat types resulting in the maximum number of species detected. Each base camp is occupied for about 10 consecutive days. During that time, various methods are used to detect mammals, birds, amphibians, and reptiles. Mammal diversity typically is recorded using a combination of Sherman live-traps (H.B. Sherman Traps, Inc., Tallahassee, Florida, https:/www.shermantraps.com) for small mammals, wire cage livetraps for larger species, small pitfall traps for shrews, and acoustic detectors for recording bat calls. Birds are sampled using timed point-count transects (Ralph and others, 1995), whereas reptiles and amphibians are detected using 5-gal pitfall traps and opportunistic searches in suitable habitats. The number of traps can vary, but traps typically number 240 Sherman traps, 15-20 wire-cages, 50 small pitfalls, and 10 large pitfalls. Timed point-count transects number between 5 and 10 per site depending on the requirements of the statistical analysis to be performed. Details on trap deployment, the distribution of traps in the sampling site, and length of sampling periods are described in Grinnell and Storer (1924), Patton (2006), and Moritz and others (2008).

The list of species at a sampling site is only one element of a Grinnell-style survey. An important and perhaps more significant component of the field survey is the resulting collection of data and specimens. Data are in the form of field notes and data sheets recording detailed animal measurements and the vegetation and habitat types where species were detected. Field notes provide the ecological context for where the species occurs and some basic information on habitat characteristics. 
Ideally, they describe in detail location-specific information (for example, geographic coordinates), a narrative description of the location, and any rare or unusual habitat types or features that are present.

To thoroughly document specimens collected in the field, we suggest including study skins, skulls, skeletons, whole animal specimens, DNA, and tissue. The number and types of specimens are determined by specific project needs and goals. Typically, at least two specimens (skin and skull with tissue and DNA) of each species are collected as vouchers to document species presence at each sampling site. However, exceptions can be made if a species is rare, is already known to occur, has been documented previously (for example, Siberian marmot [Marmota sibirica]), or because it is easily recognized (for example, Siberian elk [Alces alces], wolf [Canis lupus]). Specimens can serve as permanent records if they are stored at an accredited institution with rigorous curation and preservation standards.

\section{Photographic Evidence of Occurrence}

An excellent option is photographs, preferably stored digitally, to document the occurrence of larger species, observation locations, vegetation or habitat types, and any landmarks that can help relocate the site in the future. The ideal photographs will be of good quality and sufficient resolution such that they can be enlarged if necessary to aid in identification. The images represent data, ideally to be managed and curated, preferably adhering to an in-house image-management protocol that ensures consistent labeling and prevents loss or damage.

\section{Published Reports of Occurrence}

In addition to curated specimens and photographic evidence, another acceptable form of evidence to document species occurrence is good-quality publications. Published reports ideally will provide sufficient detail to document species occurrence within a protected area. Assessing author credentials and the precision of the data provided will be important for determining whether the source can be cited for reliable occurrence data. 


\section{Appendix 4. Using the International Union for the Conservation of Nature Species Mapping Tool to Generate a Potential Species List}

A potential species list for an area is useful in planning surveys, including the sampling resolution and survey techniques. The following procedure will create a list of species than can be expected to occur in an area specified by the user (that is, radius from a set of geographic coordinates) based on species distribution maps stored in the Mongolian Biodiversity Databank (modeled, not empirical data).

Enter www.nationalredlist.org/ in a Web browser address box. This will open the International Union for the Conservation of Nature National Red List Web page showing a map of the world.

Locate and click on "Mongolia" to display the link, View National Red List publications for this country.

Selecting the link opens the Mongolia Regional Red List Web page showing the Red List publications for mammals, birds, reptiles and amphibians, and fish in Mongolia. Near the top of the page, just below the National Red List link, are tabs displaying additional links.

Click on Support \& Information to display a drop-down-list.

Select Tools derived from National Red Lists/Spatial tools. This opens the Species Mapping Tool page.

Click on the link, Mongolian geographical species search midway down the page. This opens a new page showing a map of Mongolia and its aimags (provinces).

Click on the location of Tengis-Shishged National Park. Then click on Search to generate a vertebrate species list of fish, mammals, and reptiles based on species distribution maps. Repeat this step to generate species lists for the Horidol Saridag and Ulaan Taiga Strictly Protected Areas

Alternatively, if you know the geographic coordinates for the centroid of an area, you can enter the latitude and longitude in the data panel to the right of the map. Additionally, you can specify an area rather than just a single point by including a range (= radius). This may yield more expansive results because it will expand the search to include multiple habitats.

\section{Notes:}

- The species distribution maps, sometimes referred to as "limits of distribution" or "field guide" maps, aim to provide the current known distribution of the species within its native range. The limits of distribution can be determined by using known occurrences of the species, along with the knowledge of habitat preferences, remaining suitable habitat, elevational limits, and other expert knowledge of the species and its range. In most cases, the range is depicted as polygons. A polygon indicating the limits of a species distribution is essentially meant to communicate that the species probably occurs in this polygon, but it does not mean that it is distributed equally in that polygon or occurs everywhere in that polygon.

- Although the species mapping tool was projected to include birds by 2010, in August 2016, the tool did not include this taxon. 

Publishing support provided by the U.S. Geological Survey

Science Publishing Network, Tacoma Publishing Service Center

For more information concerning the research in this report, contact the Director, Western Ecological Research Center

U.S. Geological Survey

3020 State University Drive East

Sacramento, California 95819

http://www.werc.usgs.gov/ 
\%

高. 